\title{
Who's to blame or praise? Performance attribution challenges in outsourced service provision in supply chains
}

\author{
Final Version \\ Accepted for publication to the Supply Chain Management: An International Journal \\ In Press: To Appear in Volume 21, Issue 5
}

\author{
Dr Kostas Selviaridis \\ Department of Management Science \\ Lancaster University Management School \\ LA1 4YX, Lancaster, United Kingdom \\ Tel.: +44(0)1524594602 \\ Email: k.selviaridis@lancaster.ac.uk
}

June 2016 


\title{
Who's to blame or praise? Performance attribution challenges in outsourced service provision in supply chains
}

\begin{abstract}
Purpose: The aim of this paper is to understand the antecedents and effects of performance attribution challenges arising in the provision of business-to-business (B2B) services in supply chains.
\end{abstract}

Design/methodology/approach: The study draws on three in-depth case studies of logistics service providers (LSPs) offering supply chain solutions to their clients in Sweden. The analysis of performance attribution challenges and their antecedents and effects is based on 38 semi-structured interviews and review of 43 documents, including contracts and performance monitoring records.

Findings: Three key antecedents of performance attribution challenges are stressed. Two of these, the inseparability and contestability of service inputs, are closely related to the notion of service co-production. The third antecedent is the limited provider capability in performance data collection and analysis. Performance attribution challenges may result in provider aversion to performance-related risk and have a harmful effect on client relationships e.g. in terms of provider perceptions of opportunism and unfair allocation of gains. These effects can be mitigated through contracting, interventions in performance measurement system design and deployment of relational mechanisms.

Research limitations/implications: The paper extends the service management literature emphasising service co-production by suggesting that inputs of the client firm and its supply chain partners may not only vary in quality but can also be inseparable from provider inputs, and highly contestable. It also empirically demonstrates how performance attribution challenges and their antecedents and effects manifest themselves in B2B service provision, as opposed to supply chain settings where the main user of logistics services is the consumer.

Practical implications: LSP managers should contract for performance based on highquality and incontestable external inputs they rely upon. Contractual specifications (performance indicators and related incentives) should explicate and consider the inputs required by clients and their supply chain partners in order to minimise their contestability.

Originality/value: The study proposes an empirically-based framework of the antecedents and effects of performance attribution challenges, an issue that has received scant attention in logistics outsourcing research and the business services literature more broadly.

Keywords: performance management; contracts; service delivery; supply chain management; case studies 


\section{Introduction}

The aim of this paper is to empirically understand the antecedents and effects of performance attribution-related challenges arising in the provision of business-to-business (B2B) services in supply chains. Attribution of service performance is defined in this study as the search for causes of service delivery failures and/ or achievements with particular emphasis on the locus of such causes i.e. what or who to blame /praise (Oflac et al., 2012; Hess et al., 2003). Performance attribution in supply chain contexts presents challenges in that the existence of multiple actors creates complexity in determining what or who is to be held responsible for product or service failures (Oflac et al., 2012).

The study examines performance attribution in the context of logistics services. Locating causes of service delivery failures /achievements is rather complicated in advanced logistics service provision whereby logistics service providers (LSPs) act as 'supply chain integrators' (Liu and Wang, 2015) and coordinate the inputs of multiple actors e.g. service subcontractors, the client and its supply chain partners (Selviaridis and Norrman, 2014). Attribution of service delivery failures /achievements in these settings refers to multiple facets and dimensions of performance (e.g. information management, supply chain design and planning, cost management, and physical distribution activities) which are managed as a whole by the LSP integrator (Shi et al., 2016; Krakovics et al. 2008). The operational complexity arising from multi-actor contribution to multi-dimensional service delivery performance makes it challenging to clearly attribute performance to LSP effort and inputs, as opposed to the inputs of the client and other parties contributing to service delivery (Hartmann and de Grahl, 2012).

Performance attribution-related challenges and their antecedents and effects are examined in this study from a service provider vantage point. This is because a limited ability to clearly attribute service delivery performance to LSP inputs may have significant implications for 
LSP firms in terms of client satisfaction as well as incentive alignment with clients through risk and gain sharing. A limited ability to attribute service delivery failures /achievements (against the agreed performance levels) to provider inputs can result in client dissatisfaction with the LSP even in cases where the actual cause of a service failure lies with other parties, or the client firm itself. On the other hand, a positive contribution of the LSP to the client's supply chain performance may go unnoticed by the client firm if it cannot be clearly attributed to LSP inputs and effort, and may even result in the client firm attributing positive performance outcomes to itself (rather than to the LSP). Overcoming performance attribution-related challenges can help increase transparency in relation to the inputs required by the client, its supply chain partners and service sub-contractors for successful LSP service delivery and, in this sense, facilitate also collaborative service delivery and performance improvement (Yang and Zhao, 2016).

Beyond improved client satisfaction and collaboration, clear attribution of service delivery performance can help align LSPs' goals and incentives with those of their clients. Specifically, it can make LSPs more willing to share performance-related risks with their clients, insofar as service delivery failures would be clearly attributable to inputs and actions of the provider and other collaborating parties. Similarly, performance attribution can enable the sharing of performance-related gains for the client (e.g. increasing client sales attributed to LSP improvement in stock availability) so as to incentivise LSP continuous performance improvement and innovation (Sanchez Rodriguez et al., 2015; Wagner and Sutter, 2012). Indeed, improved performance attribution can facilitate the deployment of value-based payment schemes (comprising revenue and risk sharing mechanisms), which is a strategic intent of large LSPs in order to combat the cost-based, competitive margins prevailing in this industry and position themselves towards the 'high-value' end of the market (Prockl et al., 2012; Lukassen and Wallenburg, 2010). 
Despite the above implications of performance attribution for providers, we have a limited understanding of this issue in logistics service provision, as well as in B2B service settings more broadly. In particular, the extant service management and logistics outsourcing literatures offer scant empirical insights into the nature of performance attribution challenges in B2B contexts, what triggers those and what theirs effects are. This paper empirically addresses these issues from a service provider perspective by posing two research questions: RQ1: What are the antecedents of performance attribution challenges in relation to outsourced service provision in supply chains?

RQ2: What are the effects of performance attribution challenges in relation to outsourced service provision in supply chains, and how are they managed?

To pursue the research questions the study draws on three in-depth case studies of LSPs providing advanced logistics services to their clients in Sweden. The analysis of performance attribution challenges and their antecedents and effects is based on 38 semi-structured interviews and review of 43 documents, notably contracts and performance records.

The paper contributes to service management literature, which has stressed the effect of variability in client inputs on service delivery quality, by suggesting that service inputs may also be inseparable and contestable and impede the attribution of service delivery performance to LSP effort, as opposed to that of the client or third parties in the supply chain. It also contributes to existing literature by empirically demonstrating how performance attribution challenges manifest themselves in B2B service settings, what their antecedents and effects are, and how such effects can be managed. The findings suggest implications for LSP managers involved in contracting and performance management, e.g. by accounting for contestable inputs required by clients to positively influence service delivery.

The rest of the paper is structured as follows. The next section reviews the relevant literature, and Section 3 discusses the research methodology. Section 4 provides the within- 
case descriptions and analyses, whereas Section 5 presents the cross-case analysis and discusses the findings. Section 6 concludes and draws out research and managerial implications as well as future research opportunities.

\section{Literature review}

This section outlines the implications of advanced logistics service provision for performance management, specifically for the design and management of logistics service performance measurement systems and contracts. It then discusses performance attribution in relation to business services provision and presents a preliminary analytical frame of the antecedents and effects of performance attribution-related challenges facing service providers.

\subsection{Logistics outsourcing}

The logistics outsourcing literature collectively suggests that LSPs have assumed a strategic role in the supply chains of their clients (Yang and Zhao, 2016) as the latter increasingly draw on external expertise and capabilities to improve their supply chain performance in terms of service levels, cost efficiency and environmental sustainability (Rossiter Hofer et al., 2015; Rossi et al., 2013; Gotzamani et al., 2010). This phenomenon is termed 'third party logistics' (3PL) and refers to the organisational practice of contracting out logistical activities (e.g. transportation and warehousing), which had previously been performed in-house, to specialist providers (Hwang et al., 2016; Selviaridis and Spring, 2007). Responding partly to client requirements for value-added services, and partly to pressures to extend margins through differentiation, many LSPs have moved from transport- and warehouse-oriented offerings to the provision of integrated supply chain solutions to their clients (Shi et al., 2016; Martikainen et al., 2014). An example of advanced service provision is the 'fourth party logistics' (4PL) concept, which is defined in the literature as a non-asset based business 
model (Van Hoek and Chong, 2001) whereby LSPs bear responsibilities of designing and planning supply chains and managing global logistics flows on behalf of their clients (Evangelista et al., 2012; Hingley et al., 2011). In advanced service provision LSPs rely on collaborating providers for physical distribution capabilities and assets (e.g. transportation modes and warehouses). The LSP essentially assumes the role of a logistics integrator bringing together complementary service systems, resources and capabilities and managing them as a whole to improve the client's supply chain performance (Liu and Wang, 2015).

It has also been suggested that the provision of advanced services entails increasing complexity in measuring and managing outsourcing performance since: (a) performance has multiple dimensions (Krakovics et al., 2008), and (b) service provision requires coordinating multiple parties, in addition to the LSP, that all contribute to service delivery (Liu and Wang, 2015; Büyüközkan et al., 2009). In order for LSPs to demonstrate their contribution to performance improvement and innovation and potentially share related gains with the client (Grawe et al., 2015; Wagner and Sutter, 2012), there need to exist mechanisms for reviewing performance outcomes and attributing causes of service failures or achievements to LSP inputs, as opposed to those of the client or collaborating parties. Hence, the literature draws attention to the design and implementation of performance metrics and payment schemes included in contracts (e.g. Sanchez Rodriguez et al., 2015; Lukassen and Wallenburg, 2010).

\subsection{Measuring and managing logistics service performance}

The role of performance measurement and management systems in successful outsourcing relationships is stressed in the literature, as they allow controlling the provider's performance, identifying areas of service improvement, and eventually increasing business and financial performance of the client firm (e.g. Gunasekaran et al., 2015; Jayaram and Tan, 2010; Van Hoek, 2001). Existing studies of logistics service performance measurement and management 
appear to focus on the definition and design of suitable key performance indicators (KPIs) and the development of effective measurement methodologies (Huo et al., 2015; Rajesh et al., 2012; Krakovics et al., 2008). A large suite of performance metrics have been proposed including delivery timeliness, order fill rates, picking accuracy, inventory turns and cost savings (Sanchez Rodriguez et al., 2015; Hsiao et al., 2010; Hamdan and Rogers, 2008). The literature also points at potential performance trade-offs that have to be made e.g. higher levels of delivery reliability can compromise potential cost reductions resulting from consolidation (Leung et al., 2013). While some studies tend to focus exclusively on internal performance measures for LSPs (e.g. Kayakutlu and Buyukozkan, 2011; Min and Joo, 2006; Lai et al., 2004), the majority often encapsulates also customer-facing measures and targets e.g. service levels improvement, cost reduction and flexible pricing (see Rajesh et al., 2012; Büyüközkan et al., 2009).

The literature also stresses the increasing complexity of performance measurement and management in advanced logistics service provision in that deployed metrics and performance monitoring systems are not only oriented towards the LSP, but also reflect the performance obligations of contracted transport and warehousing companies and any third parties contributing to service delivery (see Krakovics et al., 2008). However, there is little evidence as to whether the obligations of clients (in terms of the inputs they must contribute) are also reflected in the agreed performance metrics and monitoring systems.

In addition to performance measurement systems, the role of formal contracts in monitoring LSP performance and incentivising its improvement has been stressed (Huo et al., 2015; Marasco, 2008). More specifically, the literature emphasises the role of contracting in allocating performance-related risks and gains and agreeing payment schemes that help to align the goals of LSPs and their clients (Yang et al., 2016; Wu et al., 2015; Wagner and Sutter, 2012). A particular contract type emphasising explicit incentives for performance 
improvement is the performance-based contract (PBC). This ties the provider's payment to the achievement of well-specified performance targets, hence transferring performancerelated risk to the LSP (Jin et al., 2015; Logan, 2000). In practice it often entails the design of an incentive fee (financial penalty/ bonus) as a percentage of the total service fee (usually fixed or unit price) that is paid out to the service provider (Doerr et al., 2005).

Clearly defined performance metrics and targets and performance measurement capabilities are necessary conditions for successful use of PBCs (Forslund, 2012). Existing research, however, has identified several barriers of leveraging PBCs to manage and improve service performance, such as customer reluctance to offer extra rewards in exchange for LSP risk taking, excessive investments required in performance monitoring systems, and lack of LSP capabilities to measure and analyse performance (Selviaridis and Norrman, 2015; Whipple and Roh, 2010; Logan, 2000). Challenges facing LSPs in relation to performance measurement also include the limited ability to attribute service failures /achievements to the LSP, as opposed to the client and other parties co-producing service delivery (Hartmann and de Grahl, 2012). Despite its importance for LSPs, the latter challenge has hitherto been underplayed in the existing literature. Specifically, there is scant empirical evidence of what causes performance attribution-related challenges, what their effects are, and how such effects can be managed. This issue is addressed in the following section.

\subsection{Performance attribution challenges}

Performance attribution concerns the search for causes of service delivery failures or achievements and specifically for the locus of such causes i.e. what or who to blame /praise (Hess et al., 2003). Generally speaking, performance failures tend to instigate more attributional searches than achievements because individuals or organisations perceive negative events as more impactful (Folkes, 1984). Locating causes of performance failures or 
achievements in supply chains is complicated owning to the fact that multiple parties contribute to product /service delivery (Oflac et al., 2012), as well as due to the generic tendency of individuals or organisations to attribute positive outcomes to self, and negative to others (Folkes, 1984). Performance attribution issues in logistics service delivery has attracted limited attention (see Oflact et al., 2012; Hess et al., 2003) with existing studies focusing on business-to-consumer (B2C) settings and underplaying the antecedents and effects of related challenges in B2B service contexts. The rest of this section draws on service management literature and agency theory to present a preliminary analytical frame of performance attribution challenges facing service providers, and their antecedents and effects.

The existing service management literature implicitly associates performance attribution challenges with co-production, which is seen as an inherent feature of service exchanges (Sampson, 2000). Two different literature streams emphasise service co-production. The unified services theory posits that customers of a service simultaneously act as suppliers of inputs (e.g. information and their material possessions) into service production and delivery (Sampson and Froehle, 2006). In this sense, supply chains of services involve bi-directional input flows (Sampson, 2000). In the context of advanced logistics services this means that the client firm and perhaps other users of the logistics services (e.g. the client's customers) are required to contribute their inputs (e.g. information or other resources) into service delivery, which is designed and executed by the LSP in coordination with contracted transport and warehousing operators.

Customers of services may assume multiple roles in service delivery, e.g. provide labour and essential service process components, or design service production processes (Sampson and Spring, 2012). The implication of this duality of the customer as a 'supplier of inputs' is that service delivery performance is directly influenced by the quality of inputs provided by the customer. A key challenge for service providers then is to manage the variability of 
customer inputs into the service delivery process (Sampson and Froehle, 2006). Relating again to logistics services, this means that the LSP must ensure, for instance, that the client offers timely and accurate information regarding sales forecasts and product volumes. And that, in the example of returnable packaging services, the client's suppliers return empty packages in a timely fashion to ensure package availability for delivery of parts to the client's production facility (see Selviaridis et al., 2016).

The second literature stream that stresses co-production and value co-creation through close interactions and coordination of activities between service providers and their customers is the so-called service dominant logic (SDL) (e.g. Randall et al., 2010; Vargo and Lusch, 2004). SDL suggests too that the customer provides inputs into service delivery and tends to focus on relational mechanisms to manage co-production, specifically referring to collaboration and information and knowledge sharing (Randall et al., 2011; Ng et al., 2009) to ensure successful service delivery. It underplays, however, relevant contractual responses to the risks of service co-production. A key concern in co-production is opportunistic behaviour (Wallenburg and Schäffler, 2014) and specifically the condition of 'shirking', whereby one or more parties involved in team work may intentionally reduce their effort and free-ride on the output of co-production. Since the outcome of co-production is often more than just the sum of individual inputs and contributions, as synergistic effects are at play, it may be difficult to detect which party is 'shirking’ (Alchian and Demsetz, 1972).

Contract theory has long focused on opportunism effects associated with joint production (Foss and Stea, 2014; Jensen and Meckling, 1976). In particular, principal-agent theory seeks to address such moral hazard problems by designing contracts that minimise agency costs related to performance monitoring and risk bearing (Halldórson et al., 2015; Feldman and Montgomery, 2015). The choice between behaviour- and outcome-based contracts is determined by factors pertaining to the service exchange characteristics and the attributes of 
actors involved in service delivery (Wynstra et al., 2015; Fayezi et al., 2012). Outcome uncertainty, outcome measurability, and risk aversion of agents and principals are especially pertinent to the managerial challenge of monitoring and attributing performance (Eisenhardt, 1989). Performance can be less readily measured and attributed in situations of joint (service) production (Zhang et al., 2015). In addition, variability in performance can result from uncertain environmental factors that cannot fully be anticipated (Eisenhardt, 1989). Low outcome measurability and high outcome uncertainty introduce performance-related risk for principals (clients) and agents (providers) and may discourage them from designing an outcome-based contract, depending also on their degree of aversion to performance risk (Liu and Wang, 2015; Whipple and Roh, 2010). Provider risk aversion makes an outcome-based contract less attractive since transferring risk to the LSP becomes expensive (i.e. requires risk premium payments), whereas client risk aversion makes it more attractive (Logan, 2000). When outcome-based contracts are preferred, their design may also reflect an appropriate risk allocation through the payment mechanism so that provider compensation is proportionate to the risk taken (Selviaridis and Norrman, 2015; Kim et al., 2007).

In sum, service management literature and agency theory appear to complement each other in terms of analysing performance attribution challenges in B2B service provision. A key antecedent of attribution challenges facing providers (e.g. LSPs) is service co-production since the performance outcome is largely co-produced jointly with clients and even third parties contributing inputs into service delivery. The service users (i.e. client firms and their customers /suppliers), in particular, serve as suppliers of inputs and, therefore, directly influence (logistics) service performance. In addition, outcome (performance) measurability and uncertainty may influence the ability to attribute service delivery performance to specific actors. In terms of their effects, performance attribution challenges may discourage LSPs from signing up to performance-based incentive systems. They may also have negative 
effects for LSPs in terms of managing client relationships when the limited ability to attribute performance incentivises 'shirking' behaviour. The literature suggests that such effects can be managed through relational and /or contractual mechanisms. This preliminary analytical frame is employed to the empirical study presented in the following sections.

\section{Research methodology}

The study adopted a multiple case embedded design (Yin, 2003) following rigorous procedures for case selection, explication of the unit of analysis, theoretical framing, data collection using multiple sources of evidence, within- and cross-case analyses and discussion of findings against existing literature and theories, as recommended by Barratt et al. (2011) and Ketokivi and Choi (2014).

Given the scant empirical evidence on performance attribution challenges in the context of logistics services (and B2B service provision more broadly), the multi-case study design was deemed suitable for developing an understanding and building theory through in-depth analysis of the specific setting and its particularities (Ketokivi and Choi, 2014; Voss et al., 2002). The unit of analysis was the antecedents and effects of performance attribution challenges facing LSPs. In other words, analysis referred to the (LSP) firm level. Challenges facing LSPs in relation to performance attribution do have implications for how LSPs manage their relationships with clients and sub-contractors, but such implications were examined from a LSP firm vantage point. The embedded case design allowed studying multiple aspects of performance attribution challenges including service delivery aspects (and related LSP interactions with multiple supply chain parties), and contractual and performance management aspects (e.g. LSP interactions with clients and sub-contractors to design contracts and monitor performance). 
Three in-depth case studies of LSPs operating in Sweden and providing advanced services to their Swedish clients were conducted. Table 1 presents the background information about the case companies (including the client companies), and Table 2 depicts the agreed KPIs and payment mechanisms per case study. The cases were purposefully selected (Patton, 1990) following a replication logic and including both 'literal' and 'theoretical' replication-oriented selection criteria (Yin, 2003). Literal replication applies when a case is selected to predict similar findings, whereas a theoretical replication applies when a case is selected to predict contrasting findings, but for predictable reasons (Yin, 2003). Regarding literal replication, three basic selection criteria were applied: (a) that all selected LSP firms would provide advanced logistics services to their clients, (b) service delivery performance would have multiple dimensions and be reflected by multiple KPIs, and (c) that all selected LSP firms, regardless of their size, would be facing performance attribution-related challenges. In terms of theoretical replication, the following case selection criteria were applied: (a) service scope, considering also the client's industry features and logistical requirements (i.e. extent of valueadded services provided to clients), and (b) the number of actors involved in service delivery.

\section{[Insert Table 1 about Here]}

[Insert Table 2 about Here]

The intention with applying the above criteria was to identify theoretically important similarities and differences (Flyvbjerg, 2006) across the cases regarding the antecedents and effects of performance attribution challenges facing LSPs, as well as how such effects are managed. For instance, it was expected that the multi-dimensionality of service performance would create difficulties in terms of LSP performance data collection and analysis across all cases. On the other hand, it was envisaged that differences in service scope and the number of 
actors involved in service delivery, reflecting differences in the complexity of service provision, would have a bearing on extent of LSP dependence on service inputs provided by clients and third parties. The analysis partly confirmed such expectations, but revealed additional explanations for the observed differences across the cases (e.g. relative importance of relational and contractual mechanisms to manage effects of attribution challenges).

In line with the study's focus on the LSP perspective, the unit of observation was individual senior and middle managers of LSP firms, although access was also opportunistically sought to interview managers from two service sub-contractor firms (Case B and C) and a client firm (Case A). Overall, data collection consisted of 38 semi-interviews, which enabled interviewees to express their views (Miles and Huberman, 1994) with regard to performance attribution challenges. The interviews addressed, amongst other themes, performance measurement and management issues, performance attribution challenges and their antecedents and effects (e.g. co-production in logistics services provision, LSP willingness to bear risk). Appendix A presents the interview guide. This was employed flexibly during the interviews considering the (functional) expertise of the interviewee (see details below). For example, LSP operations managers were often less knowledgeable about contract design aspects, and hence relevant questions were either omitted or responded to in brief, and at a high level of detail. On average, the interviews lasted one and a half hours.

Two specific criteria for selecting interviewees from the LSP firms were employed: (a) that these managers would relate to and be knowledgeable about performance attribution issues, and (b) they would represent different functions within the LSP firm, as performance attribution issues relate to operational aspects of service delivery, contractual and performance management aspects, and even service design aspects. Indeed, the LSP managers interviewed spanned multiple functions including Operations, Sales and Business 
Development (BD), Key Account Management (KAM), Purchasing, and Legal. A list of interviewees per case study is provided in Appendix B.

In addition to the interviews, 43 relevant organisational documents and archival records (notably contracts of LSPs with clients and service sub-contractors, and KPIs and payment schemes) were collected and analysed. Access was also granted to performance records and related procedures for monitoring service performance of the LSP and the contracted transport and warehouse operators. These documents helped to triangulate interviews with LSP managers and thus ensure validity (Voss et al., 2002). They also proved useful in terms of seeking clarifications from interviewees (Marshall and Rossman, 1999) in instances of contradicting evidence or disagreements (e.g. specific approaches to performance monitoring). In addition, documentary evidence offered some insights into the clients' and sub-contractors' perspectives (especially documents that clients and/ or sub-contractors jointly produced with the LSPs e.g. service level agreements). Nonetheless, it is recognised that such insights were rather limited, and that further research is needed to capture the perspectives of these actors in relation to performance attribution challenges and their antecedents and effects (see Section 6.3).

The data coding and analysis procedure followed recommendations by Miles and Huberman (1994) and Yin (2003). Data were initially classified according to their source (interviews and documents), and were analysed to identify key themes (e.g. performance attribution challenges). Secondly, all data were re-grouped per case study to facilitate withincase understanding, and analysis of the key concepts and their interrelations (Barratt et al., 2011). Thirdly, codes were assigned manually to interview transcripts and document sections following an open coding procedure (Strauss and Corbin, 1990). Open codes were derived both from the preliminary analytical frame as well as themes emerging during the interviews (Voss et al., 2002). For example, empirical findings suggested that service co-production 
relates to inseparable and contestable inputs of multiple parties contributing to logistics service delivery. Fourthly, these codes were re-classified into more generic categories of antecedents and effects of performance attribution challenges through axial coding (Strauss and Corbin, 1990). As an example, the super-code 'antecedents' included the following lower-level codes that were grouped together: 'service co-production', 'inseparable inputs', ‘contestable inputs’ and 'limited data collection/ analysis capabilities'.

The third and fourth steps entailed both within- and cross-case analyses (Yin, 2003) making also use of tables (see Sections 4 and 5). A pattern matching approach was employed to make sense of the collected data and identify similarities and differences across the cases (Yin, 2003) in relation to the antecedents and effects of performance attribution challenges. Although the cases exhibited many similarities in terms of performance attribution antecedents, differences in terms of the effects and their management were also observed (e.g. approaches to performance measurement system design).

The validity and reliability of findings were addressed using four criteria: internal, construct and external validity, and reliability (Yin, 2003). Internal validity was addressed by drawing on different literatures (e.g. service management literature and agency theory) to discuss cross-case findings, and representing the data in tabular forms (Gibbert et al., 2008). Construct validity was ensured by multiple actions e.g. interviewing LSP managers from multiple functions, and triangulating interview data with contract documents (Schwenk, 1985). External validity was partly addressed by writing up and presenting detailed withincase analyses to enable transferability (Voss et al., 2002), while reliability was increased by developing an interview guide, creating a database containing all primary data (e.g. interview transcripts), and documenting the data coding and analysis process (Yin, 2003). 


\section{Within-case description and analysis}

This section describes and analyses each case study in terms of the antecedents and effects of the observed performance attribution challenges facing LSPs.

\subsection{Case A}

This case concerns a logistics outsourcing contract with the LSP managing all equipment deliveries to the packaging manufacturer's end customers, planning transport movements and managing a network of trucking companies, airlines and shipping lines. The LSP and the client firm agreed to measure and manage performance using several KPIs which are also partly tied to the provider's payment (see Table 2). The LSP (and to some extent the client also) experienced challenges of attributing performance in terms of freight cost reduction, carbon emissions reduction, on-time deliveries, and innovation outcomes. Table 3 provides empirical evidence, in the form of quotes from the interviewed managers, regarding the observed attribution challenges in Case A and their antecedents and effects. A brief description of these is provided below.

\section{[Insert Table 3 about Here]}

Antecedents. The difficulty to attribute service performance is linked to service coproduction and specifically to the challenging task of clearly separating or agreeing upon the required inputs amongst the multiple actors involved in logistics service delivery. The CO2 emissions reduction target is closely dependent on the decisions and actions of the client and its end customers (e.g. in terms of ordering patterns and production planning to minimise rushed deliveries) as well as on sub-contractor capacity planning. These inputs are challenging to separate from the LSP's effort to reduce the use of air freight deliveries. 
Regarding freight cost reduction targets, LSP interviewees again stressed the role of the client and its input in terms of providing timely and accurate order information.

Likewise, the LSP and client firms faced challenges in terms of defining their respective inputs in identifying and implementing service innovations. Although client interviewees suggested that some of the innovative ideas claimed by the LSP had actually been identified by them, LSP managers contradicted this and stressed the client's required input if service process innovations are to be realised (e.g. changes in product design and packaging). In terms of on time ocean freight deliveries, LSP managers suggested that they are heavily dependent on the inputs of shipping lines in terms of reliability of their schedules. In addition, the effect of uncontrollable inputs (such as freight market rate developments, congestion at ports and airports and extreme weather) on service delivery and freight cost reduction, and the need to discuss with the client how these should be managed, was stressed. Attribution challenges were also due to the limited LSP capability in performance data analysis, as both LSP and client interviewees suggested. Regarding innovation outcomes specifically, the LSP lacked a process of documenting its innovative ideas and tracking their implementation.

Effects and their management. The above performance attribution issues made the LSP cautious in terms of bearing financial risks in connection to the contractual performance incentives. The incentive fee represented only 1 percent of the total annual service fee reflecting the LSP's delimited risk and the parties worked to re-design some of the KPIs (e.g. $\mathrm{CO} 2$ emissions reduction) to ensure that their definitions and measurement methodologies were appropriate. The performance attribution challenges faced by LSP created some strain in its relationship with the client. LSP managers perceived the performance incentives as unfair since they felt many delivery failures were beyond their control. The imposed financial penalty for LSP failure to hit carbon emissions reduction and delivery accuracy targets was eventually not paid as the client firm recognised its contribution to service failures. This 
decision was taken as a gesture of good faith to re-instigate fairness and collaboration, as explained by the interviewed client managers. LSP interviewees were also dissatisfied with the client's opportunistic adoption of innovative ideas the LSP presented in informal meetings and without those being credited as the provider's initiative. The LSP's weakness in terms of data analysis was partly addressed by building into the performance measurement system 'controllability' and 'accountability' indices to capture uncontrollable factors and identify parties responsible for failures respectively. Three-way performance review meeting among the LSP, the client and transport sub-contractors were also introduced to analyse performance failures and rectify them.

\subsection{Case B}

This case concerns an outsourcing relationship where the LSP is responsible for managing the client's supply chain e.g. in terms of product purchasing, inventory management, demand forecasting, logistics network design, and supply chain planning. The parties agreed on multiple KPIs with the main ones being product availability at stores and supply chain cost reduction, which are also tied to a bonus payment for the LSP (see Table 2). Attribution challenges mainly referred to the supply chain cost reduction KPI target, as it proved difficult to attribute to LSP actions the potential and actual cost savings. Table 4 presents the key empirical findings, which are also briefly described in the following.

\section{[Insert Table 4 about Here]}

Antecedents. The difficulty to attribute cost reduction outcomes to LSP effort partly resulted from the inability to meaningfully separate the inputs of the transport and warehousing sub-contractors and the LSP to such outcomes. Interviewees stressed that the 
essence of third party warehousing and transportation activity is that asset investments and costs are spread across multiple clients in a way that it is challenging to single out individual contributions to cost synergies. The lack of detailed data to be able to accurately allocate cost savings resulting from LSP planning and sub-contractor cost efficiencies was also stressed by LSP interviewees, and this added to cost savings measurement and attribution difficulty. Another issue was that the client's input in terms of varying product volumes was not easily separable from LSP actions to increase supply chain cost efficiency. Increased (reduced) volumes in the supply chain could increase (reduce) scale economies regardless of LSP effort. Similarly, LSP effort to improve cost efficiency (e.g. reduced store delivery frequencies) could result in the client's customers (stores at national level) withdrawing their volumes from the LSP service network, thus reducing economies of scale overall.

The LSP and the client, therefore, had several intensive arguments about the inputs required by the client and its customers (stores) to deliver cost efficiency. LSP interviewees stressed that cost reduction was essentially a 'team effort' insofar as the client had to convince independent stores in different countries to accept adjustments to their service levels and operating routines. The parties also discussed the potential effects of variable uncontrollable inputs (e.g. number of stores and food suppliers, packaging and labelling regulations) and how those should be managed. The LSP suggested a model where changes in these factors would trigger a renegotiation of cost performance targets and annual service fee. The LSP also argued extensively with key sub-contractors about their role in efficient service delivery. LSP interviewees suggested that sub-contractor cost efficiency was crucial to achieve the client's supply chain cost reduction target, but the interviewed sub-contractor argued that its influence was limited due to inflexibility in transport capacity planning and lack of supply chain visibility and information sharing with the LSP. 
Effects and their management. The difficulties of attributing cost savings to LSP effort resulted in LSP concerns about bearing excessive performance risk in connection to the fixed price incentive fee mechanism. This put pressure on the LSP to mitigate financial risk by ensuring that the fixed fee element was set at an appropriate level to cover its costs and provide a basic profit margin. The bonus for cost reduction appeared to be less important for the LSP since the cost reduction targets set by the client were perceived by LSP managers as too ambitious to reach. The attribution challenges also created LSP concerns about the management of the client relationship insofar as the parties would attempt to address such challenges by specifying rigid rules for identifying parties responsible for failures. The LSP and client initially discussed a performance measurement system whereby all supply chain cost increases were to be attributed to actions of individual parties. This approach, however, was eventually rejected by LSP managers lest that it would cultivate a 'finger-pointing' culture. Emphasis was put instead on ongoing performance analysis and improvement and reliance on collaboration, trust and flexibility to be able to adjust the solution and payment structure, if it proved not to promote a win-win outcome.

\subsection{Case $C$}

This case refers to a service contract between an auto manufacturer and a LSP responsible for managing transportation and returnable packaging and other related value-add services. Performance was defined and managed in terms of specific KPI targets which were, however, not directly tied to the LSP's payment (Table 2). Challenges in terms of attributing logistics cost savings, and packaging availability and delivery precision results to LSP effort and inputs were observed in this case too. Table 5 presents the related empirical evidence.

[Insert Table 5 about Here] 
Antecedents. A first issue was the inability to accurately allocate cost savings to individual actions and inputs of the LSP and its transport contractors. Their inputs into service delivery for the specific client were difficult to separate from their services to other clients, due to transportation economies of scale and cost synergies created. A related challenge was one of measurement, as several LSP interviewees admitted that they did not have in place a sound data collection and analysis system to be able to measure and attribute cost savings and packaging availability performance to the extent that this would enable a performance-based payment scheme in the contract with the client.

Performance attribution challenges also arise from the operating interdependencies between the activities and inputs of the LSP, the client, sub-contractors and other third parties. Regarding cost efficiency targets, interviewees stressed the crucial input of the client in terms of sharing information of forecast volumes. The LSP also stressed the client's input in terms of committing to certain annual product volumes as a means of improving transport capacity planning and increasing efficiency across the service network. However, the client has been reluctant to commit to volumes with negative effects also on cost efficiency of LSP sub-contractors. The Managing Director of a key sub-contractor suggested that volume uncertainty and unpredictable spikes in transport demand compromise service capacity planning and cost efficiency.

The LSP also argued extensively with the client about the inputs of the latter and its supply chain partners in attaining packaging availability targets. Specifically, input is required not only from the client but also its suppliers, who make use of packages. Their cooperation in terms of package ordering policy, appropriate handling and allocation of packages across their other customers is required to achieve availability targets. Although the LSP tries to influence the behavior of these package users, it cannot directly control their 
input. Hence, the provider requests that the client should be responsible for ensuring that its suppliers to comply with all regulations and operating procedures of the LSP packaging pool.

Effects and their management. The difficulties of attributing performance resulted in the LSP's reluctance to bear financial risk induced by linking payment to cost savings and package availability targets. More specifically, the LSP did not accept for the KPIs to be tied to financial penalties. Bonuses did not apply either as the client was not willing to offer them as they would increase service prices. Interviews with LSP managers and particularly the Legal Counsel of the company confirmed that the experienced performance attribution difficulties made the provider less comfortable with bearing performance-related financial risk. The LSP also makes use of standard contractual terms and conditions applying in the transportation industry to delimit its liability for non-performance in terms of product damages and delays excluding also any 'consequential losses' (indirect damages) for the client. The LSP's inability to collect detailed cost data and allocate savings to specific courses of action, augmented also by client's perceived lack of transparency of service costing and pricing, put further strain in the relationship with the specific client, something that LSP interviewees admitted at the time (see Table 5).

\section{Cross-case analysis and discussion}

This section discusses the cross-case findings in terms of the antecedents and effects of performance attribution challenges facing LSPs, and the ways such effects can be managed. Table 6 provides a summary of the cross-case analysis.

[Insert Table 6 about Here] 


\subsection{Antecedents of performance attribution challenges}

Three key antecedent factors appear to result in difficulties in attributing performance to the effort and inputs of the LSP, as opposed to the inputs of its client and its supply chain partners. Two of these, inseparability and contestability of inputs, are closely related to coproduction effort in service delivery processes (Martikainen et al., 2014; Sampson and Froehle, 2006). The distinction between inseparable and contestable service inputs is mainly derived from the empirical findings. It is useful to make in that although certain service inputs can be clearly separated, the LSP and the client may well be contesting their allocation and related management responsibility. Whereas in the case of inseparability the LSP cannot clearly determine the impact of specific service inputs due to synergistic effects and interdependent operating decisions (e.g. Yang and Zhao, 2016), the notion of contestability suggests that the LSP has the ability to explicate and argue for the inputs required by the client and third parties, as well as for any uncontrollable environmental inputs affecting logistics service performance and costs. Adding to the service management literature which is mainly pre-occupied with the variability of client inputs in service delivery (Ng et al., 2009), the findings stress how inseparable and contestable inputs influence the ability to attribute performance to LSP effort. The third antecedent, limited data collection/analysis capabilities, also negatively influences the ability to analyse service delivery outcomes and measure and attribute performance to LSP inputs (see also Selviaridis and Norrman, 2015).

\subsubsection{Inseparable inputs}

Empirical evidence suggests that inputs of the various actors may be difficult to separate due to synergistic effects. In Case B, for instance, the efficiency of warehouse and transport operations of sub-contractors and the LSP's planning, all of which relate to the cost reduction KPI, were difficult to attribute to individual actions due to scale economies arising from these 
sub-contractors and the LSP serving multiple clients. Similarly in Case C cost efficiencies of LSP and service sub-contractors were impossible to pin down to specific contributions due to scale economy and synergy effects. In other words, attribution appears to be challenging when performance as a whole is greater than the sum of individual actors' service inputs (e.g. Liu and Wang, 2015; Alchian and Demsetz, 1972).

Inseparability of service inputs also results in difficulties in attributing performance to LSP input due to intertwined operating decisions affecting logistics service delivery (Hartmann and de Grahl, 2012; Eisenhardt, 1989). In case A, for example, LSP performance in terms of $\mathrm{CO} 2$ emissions reduction, which is mainly driven by the use of air freight (versus other transport modes), depends on a number of interdependent actions and decisions pertaining to the client's customers ordering behaviour and requested speed of delivery, the client's production lead time, and the sub-contractors’ capacity availability.

\subsubsection{Contestable inputs}

The empirical findings revealed also intense discussions and arguments among the LSPs, the clients and even sub-contractors about which parties (should) provide certain inputs into service delivery, and how (e.g. Huo et al., 2015; Logan, 2000). Case A provided evidence of disagreements over what inputs the client should provide in order for innovations to be realised (e.g. changes in product design). In Case B, achieving the supply chain cost reduction target requires convincing the client's customers (stores) to accept reduced delivery frequencies and adjustments in the product receipt processes to enable more efficient unloading of goods. It also requires the sub-contractor input into cost efficiency, although the interviewed sub-contractor suggested that it is offered limited leeway by the LSP to plan transport capacity. In Case C, the LSP argued extensively with the client about the role of the latter in service delivery in terms of providing timely information about forecast product 
volumes and making volume commitments. These client inputs were thought to impact LSP and transport sub-contractor capacity planning and cost efficiency. The necessary input of packaging users (e.g. the client's suppliers) to achieve the packaging availability targets was also extensively discussed, e.g. in terms of timely return of empty packages.

Contestability of inputs also refers to arguments as to who (LSP or client) should bear the responsibility for managing uncontrollable environmental inputs (Fayezi et al., 2012; Whipple and Roh, 2010). Both in Cases A and B uncertain inputs such as volatile sea and road freight market rates, regulatory market changes, and changes in supply chain structure instigated discussions about how such inputs should be managed, and by which party. Overall, input contestability in service co-production results in challenges to attribute performance to the effort of the service provider.

\subsubsection{Limited data collection and analysis capabilities}

The cross-case findings corroborate previous research suggesting that capabilities in performance data collection and in-depth analysis (e.g. Selviaridis and Norrman, 2015; Forslund, 2012) influence the ability to measure and attribute performance to LSP effort and inputs. Limited LSP capabilities to collect and analyse performance data led to significant challenges in terms of matching LSP inputs and effort to service innovation and cost reduction outcomes. In Case $\mathrm{A}$, the provider lacked the resources and competences to conduct in-depth analysis of service delivery failures with a view to identifying their causes and addressing them. In Case C, LSP interviewees admitted that their information system was limiting their ability to collect performance data and analyse the origin of such cost savings within the service network. The latter was also observed in Case B and created difficulties in attributing cost savings to client-specific logistics operations. 


\subsection{Effects of performance attribution challenges and their management}

Two key effects of challenges related to attributions of service performance to provider effort were observed: provider aversion to performance-related risk, and potential harm to client relationships of LSPs. These effects, and the ways of managing them, are discussed below.

\subsubsection{LSP aversion to performance risk}

Performance attribution challenges resulted in LSP aversion to performance-related risk (Liu and Wang, 2015; Fayezi et al., 2012) as it was challenging to either clearly separate LSP input from those of the client and other parties, or agree in advance and specify conditions under which LSPs were to be held accountable for service failures. This finding corroborates existing research stressing the connection between provider willingness to bear risk and the ability to measure and attribute performance (Selviaridis and Norrman, 2014; Kim et al., 2007). LSP aversion to financial risk related to performance fulfilment was evident in all cases. In Case C, the limited ability to measure and attribute logistics cost savings resulted in LSP reluctance to agree to cost savings-based incentives. In Case A, the LSP contested the client's role in reducing $\mathrm{CO} 2$ emissions reduction and this led to delimiting LSP in the bonus/malus scheme. In Case B, it was suggested that the intensity of the cost reductionbased incentive fee should reflect LSP input, which resulted in the cost reduction bonus being perceived of secondary importance.

\subsubsection{Potential harm to client relationships}

Performance attribution challenges facing LSPs potentially have harmful effects on their client relationships (e.g. Huo et al., 2015; Whipple and Roh, 2010), as this study demonstrated: provider perceptions of opportunism on behalf of the client and unfair distribution of performance gains and risks, and client perceptions of lack of transparency of 
service costing and pricing by the LSP. Analysis revealed that contestable service inputs and their influence in logistics service performance can create tensions regarding the fairness of the payment scheme (Case A), as perceived by providers, and create an adversarial atmosphere in the relationship with the client (Case C). It is also interesting to note that attempts to clearly specify the inputs required by each party (e.g. client) may also foster a relationship atmosphere where the provider and the client seek to blame each other for failures, as observed in Case B. Overall, challenges in relation to attributing performance to provider effort and inputs can have negative effects and result in deteriorating client relationships of LSPs. Therefore, such effects need to be managed.

\subsubsection{Managing the effects}

Three key means of managing effects of performance attribution challenges were observed.

Contracting. Providers seek to mitigate their performance risk through contract design and more specifically through the (re)design of the payment mechanism and the agreed KPIs (Wu et al., 2015; Kim et al., 2007). In Case A, the LSP's risk was delimited given that the designed bonus/malus scheme, as percentage of the total annual service fee, had relatively limited financial impact on the provider. In this case the measurement method of certain KPIs was adjusted too, to reflect previous difficulties in measuring and attributing performance. In

Case B, similarly, the LSP managers emphasised the need to set the fixed fee to a level that would help cover its financial risk and offer also a reasonable margin. Since the client's supply chain cost reduction expectations were dependent on inputs beyond the provider's control, the bonus (connected to cost reduction) was perceived by LSP interviewees of secondary importance to the agreed payment scheme. Contracting was also mobilised in Case C by the LSP to mitigate its performance risks. In particular, the provider refused to tie its payment to KPI targets and also capped its liability for product damages and/or delayed 
deliveries. All of the above suggest that contract design is a key mechanism through which providers can achieve an appropriate allocation performance risk vis-à-vis their clients (Eisenhardt, 1989).

Performance measurement and management system design. The structure of the performance measurement system can help providers manage the potentially harmful effects of attribution challenges on client relationships (Gunasekaran et al., 2015). Comparison between Case A and B suggests, however, that two different approaches were followed. In Case A, the LSP in joint with the client opted for attribution-related indices ('controllability' and 'accountability'). These were also referred to in the contract as a means of increasing transparency of the inputs of the LSP and other parties on performance. This suggests that logistics service performance measurement systems can go beyond identifying improvements (Forslund, 2012; Krakovics et al., 2008) and address attribution-related challenges through the inclusion of specific indices supporting performance measurement and analysis. In Case $\mathrm{B}$, the LSP abstained from that logic and instead emphasised the need to analyse performance and identify corrective actions and act upon them on an ongoing basis. LSP interviewees felt that attribution-related indices would foster a 'finger-pointing' culture and potentially put strain on the client relationship.

Relational mechanisms. In addition to employing contracting and performance measurement systems, providers appear to stress the deployment of relational mechanisms (Yang et al., 2016; Randall et al., 2010) to manage the potentially harmful effects on their relationships with clients. More specifically, collaboration ('team effort'), trust, and win-win mentality were referred to by LSP interviewees in Case B as a means of supporting the ongoing performance analysis and improvement approach taken. Flexibility in adjusting the agreed incentive payment system was also stressed as a way to achieve win-win outcomes in joint with the client. In Case A, LSP interviewees and client managers referred to a 
collaborative attitude and the need to ensure fair allocation of financial gains (cost savings). Overall, extra-contractual responses can be important for ameliorating problems of provider perceived opportunism and re-instituting fairness in the distribution of gains arising from LSP-driven performance improvements (Rossiter-Hofer et al., 2012).

\subsection{Summary and conceptual framework}

Figure 1 summarises the above findings in the form of a framework of the antecedents and effects of performance attribution challenges. The proposed framework extends, through the empirical study, the preliminary analytical frame discussed in Section 2 by stressing: (a) the role of inseparable and contestable inputs in service co-production. Contestable inputs may also include uncontrollable environmental factors increasing uncertainty in relation to service delivery performance, (b) the design of the performance measurement and management system, in addition to relational and contractual mechanisms, as a means of managing the potentially harmful effects of performance attribution challenges facing service providers, and (c) the (re)design of the payment mechanism and performance metrics as a means of LSPs delimiting their risk, even when performance-based contracts with clients are adopted.

[Insert Figure 1 about here]

The framework suggests that the ability to attribute performance to service provider effort and inputs is influenced by the extent to which such service inputs are: (a) inseparable from inputs of other actors, due to interdependent operating decisions and synergistic effects arising from joint effort, and (b) contestable in terms of their provision (i.e. who should provide them), their uncertain effects, and the allocation of responsibility for managing such 
effects. In addition to these two factors, the limited ability of service providers to collect and analyse performance data results in performance attribution challenges.

Performance attribution challenges may in turn result in LSP aversion to performancerelated risk and can have a harmful impact on client relationships (see Figure 1), e.g. provider perceptions of opportunism on behalf of the client and unfair distribution of gains arising from LSP-driven performance improvements. Regarding the management of such effects (Figure 1), contracting is used to address the provider's aversion to performance risk. In particular, the provider's financial risk is mitigated through the design of the payment mechanism. The potential harm to client relationships is managed through performance management systems (including attribution-related indices or stressing interim reviews and in-depth performance analyses), and the deployment of relational mechanisms i.e. emphasising collaboration, trust, win-win mentality and distributive fairness. In addition, Figure 1 captures the empirical observation that contracting can also have a bearing on the design of performance measurement systems by adjusting KPIs and measurement methods.

\section{Conclusions and implications}

This paper has sought to empirically understand the antecedents and effects of performance attribution challenges arising in outsourced service provision in supply chains. The proposed framework (Figure 1) provides answers to the two research questions posed by stressing the inseparability and contestability of service inputs and the limited LSP capability to collect and analyse performance data as key antecedents (RQ1), and the provider's aversion to performance risk and the potential harm to client relations as key effects. These effects can be managed through contracting, performance measurement systems and relational mechanisms (RQ2). The implications of these findings for service management and logistics outsourcing literatures are discussed below. 


\subsection{Research implications}

The proposed framework extends the service management literature emphasising service coproduction (Sampson and Spring, 2012; Randall et al., 2010) by stressing two additional characteristics of service inputs provided by the service provider, the client and/ or other supply chain parties contributing to the delivery of business services. The findings regarding the inseparability and contestability of service inputs extend the existing literature which emphasises the variability of client inputs and its importance for service delivery performance (Martikainen et al., 2014; Sampson and Froehle, 2006). The proposed framework suggests that client and third party inputs may not only vary in quality, but they can also be inseparable from provider inputs, and highly contestable. The empirical study demonstrates how the inseparability and contestability of inputs influences the ability to attribute service delivery failure / achievement to provider inputs (Yang and Zhao, 2016).

The study also contributes to the scant literature on attribution of logistics service performance in B2C settings (Oflac et al., 2012; Hess et al., 2003) by stressing the inputs required by service users (i.e. the client and its customers or suppliers) in B2B contexts, and how such requirements are handled in the contractual relationship between the provider and the client. In B2C contexts the end user of services (i.e. the consumer) may attribute product delivery failures to the LSP, rather than the manufacturer of brand (who contracts with the LSP) on the basis of high brand expectations or purchase criticality. These are factors beyond the control of the LSP but also, crucially enough, beyond that of the manufacturer. In such settings the consumer does not directly impact service delivery performance, but its perceptions of brand quality and purchase importance are instrumental in its attribution of failures (Oflac et al., 2012). In B2B settings, however, the service users are organisations whose inputs into service delivery are identifiable, and yet may be inseparable and /or contestable. Unlike B2C services where the LSP does not contract with consumers, in B2B 
settings the LSP typically has a contractual relationship with the main service user i.e. the client firm. The contract then becomes an instrument for mitigating performance-related risks by explicating inputs required by the client and its supply chain counterparts (Selviaridis and Norrman, 2014).

This study helps to increase our understanding of an important, and yet underplayed, issue facing providers (and LSPs more specifically) by empirically demonstrating what triggers performance attribution challenges in B2B service settings, what their effects are, and how these are managed. The paper also adds to the literature focusing on logistics service performance measurement systems and capabilities (e.g. Gunasekaran et al., 2015; Rajesh et al., 2012) by suggesting that performance attribution challenges have important effects on the LSP in terms of risk sharing with clients (Huo et al., 2015) and client relationship management more broadly. These effects need to be considered when designing performance measurement systems and service contracts. In this respect, the case studies reveal two diametrically opposing approaches adopted by LSPs: (a) explicitly recognising and addressing performance attribution effects through the inclusion of related indices in the contractual specification and the associated performance measurement system (Case A), and (b) choosing to underplay attribution issues and not address them formally, but emphasise instead interim reviews and continuous improvement effort (Case B). Although existing studies on outsourcing performance measurement (e.g. Gunasekaran et al., 2015; Rajesh et al., 2012; Krakovics et al., 2008) have been useful in terms of identifying and designing suitable KPIs and effective measurement and monitoring methodologies, they have hardly addressed attribution challenges and their implications for the design and execution of performance management systems.

Finally, the paper contributes to studies stressing the role of contracts in managing logistics service performance (e.g. Huo et al., 2015; Selviaridis and Norrman, 2015; Wagner 
and Sutter, 2012) by empirically demonstrating how the potentially negative effects of performance attribution can be managed through contract (re)design. More specifically, LSPs put emphasis on the design of the payment mechanism and performance metrics as a means for mitigating their financial risks (Kim et al., 2007) and reducing their exposure to performance-related incentives that may be requested by customers (see Cases A and B). In addition, contracting can be critical in terms of delimiting the LSPs' liabilities related to service delivery failures especially in situations where the ability to measure and attribute performance to the LSP effort is restricted.

\subsection{Managerial implications}

The study presents implications for LSP managers involved in contracting and the design of performance measurement and management systems. The findings suggest that successful service delivery may be heavily dependent on the inputs of clients, sub-contractors and other parties in supply chains. Such inputs can, however, be inseparable from LSP inputs or, more importantly here, highly contestable. The implication of this for LSPs is that they should contract for performance (improvement) based on high-quality and incontestable external inputs they rely upon. KPI matrices and related performance incentives should be accompanied by explicit and clear specifications of such inputs, especially those required by clients and their supply chain partners, to minimise their contestability. Contingency planning clauses may also be required in the contract to account for contestable inputs relating to market or regulatory changes, and to mitigate their potential negative impacts on service delivery performance.

Nonetheless, the findings in relation to the potentially harmful effects of performance attribution challenges on client relationships suggest that LSPs may be better off stressing joint effort with clients and sub-contractors and ongoing performance review and analysis 
with a view to proactively improving service performance, in situations where attribution indices might appear to foster a culture of mutual blame for service failures. Such an approach to performance management requires developing sound data collection and analysis capabilities, both in terms of information systems and human resources dedicated to performance management. Capability development in this area is crucial especially for LSPs coordinating the inputs of multiple parties contributing to service delivery.

Finally, from a client perspective the relative ability to isolate the service provider's effort and contribution to supply chain performance will determine the approach taken in performance monitoring and management. Outsourcing firms, as suggested above for LSPs, might need to address contestable inputs by explicitly detailing in the service level agreement conditions upon which increases in performance may not be attributable to LSP effort, but to other external factors, e.g. cost efficiency in the client's supply chain can arise from an increase in product sales and volumes and the resulting scale economies in transportation and warehousing. To the extent that this is possible, outsourcing firms can then specify instances when logistics service performance increases should not lead to bonus payments to the appointed LSPs. Such an approach can help increase transparency in relation to the allocation of gains and risks between the LSP and the client firm, and hence reinforce the level of distributive fairness as this is perceived by the contracting parties.

\subsection{Limitations and future research}

This study has taken a service provider perspective and it thus offers limited insights into the perceptions of clients and service sub-contractors in relation to performance attribution challenges, their antecedents and effects. Future research should address these issues from the vantage points of these other supply chain actors. It would be particularly interesting to study systematically the views of sub-contractors (transport and warehouse operators) employed by 
LSPs in relation to performance measurement and management, and their perceptions about their extent of control and influence over the client's supply chain performance.

The paper is based on three in-depth case studies of LSPs providing services specifically to their clients in Sweden and, as such, it present limitations in terms of external validity of its findings. The identified antecedents and effects of performance attribution challenges need to be tested through a large-scale survey covering a wider range of service providers, operating in diverse industries and across countries, and also in other, less advanced service settings (e.g. provision of basic services such as transportation).

Further research could also follow up the insights this study provided in relation to the inclusion of attribution-related indices into service level agreements and KPI matrices agreed between LSPs and their clients. Modelling studies could be particularly useful in this respect. They could potentially focus on the optimal design of attribution-related indices (considering also performance administration costs in relation to the ensuing benefits for LSPs) and their impact on gain and risk sharing between LSPs and their clients, as well as on logistics outsourcing performance more broadly. This study has provided empirical insights, but further work is required to develop a refined theoretical understanding of performance attribution issues in outsourced service provision in supply chains. 


\section{References}

Alchian, A.A., and Demsetz, H. (1972), "Production, information costs, and economic organization", American Economic Review, Vol. 62, pp. 777-795.

Barratt, M., Choi, T., and Li, M. (2011), "Qualitative case studies in operations management: Trends, research outcomes and future research implications”, Journal of Operations Management, Vol. 29, pp. 329-342.

Büyüközkan, G., Feyzioglu, O., and Ersoy, M.S. (2009), "Evaluation of 4PL operating models: A decision making approach based on 2-additive Choquet integral”, International Journal of Production Economics, Vol. 121, pp. 112-120.

Doerr, K., Lewis, I., and Eaton. D. (2005), "Measurement issues in performance-based logistics", Journal of Public Procurement, Vol. 5 No. 2, pp. 164-186.

Eisenhardt, M. K. (1989), “Agency theory: An assessment and review”, Academy of Management Review, Vol. 14 No. 1, pp. 57-74.

Evangelista, P., Mogre, R., Perego, A., Raspagliesi, A. and Sweeney, E. (2012), “A survey based analysis of IT adoption and 3PLs' performance”, Supply Chain Management: An International Journal, Vol. 17 No. 2, pp. 172-186.

Fayezi, S., O’Loughlin, A., and Zutshi, A. (2012), “Agency theory and supply chain management: A structured literature review”, Supply Chain Management: An International Journal, Vol. 17 No. 5, pp. 556-570.

Feldman, E. and Montgomery, C. (2015), “Are incentives without expertise sufficient? Evidence from Fortune 500 firms”, Strategic Management Journal, Vol. 36, pp. 113-122.

Flyvbjerg, B. (2006), "Five misunderstandings about case-study research", Qualitative Inquiry, Vol. 12 No. 12, pp. 219-245.

Folkes, V.S. (1984), “Consumer reactions to product failure: An attributional approach,” Journal of Consumer Research, Vol. 10 No. 4, pp. 398-409.

Forslund, H. (2012), "Performance management in supply chains: Logistics service provider's perspective", International Journal of Physical Distribution and Logistics Management, Vol. 42 No. 3, pp. 296-311.

Foss, N. and Stea, D. (2014), "Putting a realistic theory of mind into agency theory: Implications for reward design and management in principal-agent relations”, European Management Review, Vol. 11, pp. 101-116

Gibbert, M., Ruigrok, W., and Wicki, B. (2008), “What Passes as a rigorous case study?”, Strategic Management Journal, Vol. 29 No. 13, pp. 1465-1474.

Gotzamani, K., Longinidis, P. and Vouzas, F. (2010), “The logistics services outsourcing dilemma: quality management and financial performance perspectives”, Supply Chain Management: An International Journal, Vol. 15 No. 6, pp. 438-453.

Grawe, S., Daugherty, P. and Ralston, P. (2015), "Enhancing dyadic performance through boundary spanners and innovation: An assessment of service provider-customer relationships", Journal of Business Logistics, Vol. 36 No.1, pp. 88-101.

Gunasekaranan, A., Iranib, Z., Choyc, K., Filippid, L. and Papadopoulos, T. (2015), "Performance measures and metrics in outsourcing decisions: A review for research and applications", International Journal of Production Economics, Vol. 161, pp. 153-166.

Halldórsson, A., Hsuan, J., and Kotzab, H. (2015), "Complementary theories to supply chain management revisited - from borrowing theories to theorizing”, Supply Chain Management: An International Journal, Vol. 20 No. 6, pp. 574-586.

Hartmann, E., and de Grahl, A. (2012), "Logistics outsourcing interfaces: the role of customer partnering behavior", International Journal of Physical Distribution and Logistics Management, Vol. 42 No. 6, pp. 526-543.

Hess, R.L., Ganesan, S. and Klein, N.M. (2003). "Service failure and recovery: The impact of relationship factors on customer satisfaction”, Journal of Academy of Marketing Science, Vol. 31 No. 2, pp. 127-145. 
Hingley, M., Lindgreen, A., Grant, D.B., and Kane, C. (2011), "Using fourth-party logistics management to improve horizontal collaboration among grocery retailers", Supply Chain Management: An International Journal, Vol. 16 No. 5, pp. 316-327.

Hsiao, H., Kemp, R., Van der Vorst, J., and Omta, S. (2010), “A classification of logistics outsourcing levels and their impact on service performance: Evidence from the food processing industry", International Journal of Production Economics, Vol. 124, pp. 75-86.

Huo, B., Ye, Y. and Zhao, X. (2015), "The impacts of trust and contracts on opportunism in the 3PL industry: The moderating role of demand uncertainty", International Journal of Production Economics, Vol. 170, pp. 160-170.

Hwang, B.N., Chen, T. and Lin, J. (2016), "3PL selection criteria in integrated circuit manufacturing industry in Taiwan”, Supply Chain Management: An International Journal, Vol. 21 No. 1, pp. $103-124$.

Jayaram, Y., and Tan., K.-C. (2010), "Supply chain integration with third-party logistics providers", International Journal of Production Economics, Vol. 125 No. 2, pp. 262-271.

Jensen, M., and Meckling, W. (1976), "Theory of the firm: Managerial behavior, agency costs, and ownership structure”, Journal of Financial Economics, Vol. 3, pp. 305-360.

Jin, T., Tian, Z., and Xie, M. (2015), "A game-theoretical approach for optimizing maintenance, spares and service capacity in performance contracting”, International Journal of Production Economics, Vol. 161, pp. 31-43.

Kayakutlu, G., and Buyukozkan, G. (2011), "Assessing performance factors for a 3PL in a value chain”, International Journal of Production Economics, Vol. 131, pp. 441-452.

Ketokivi, M., and Choi, T. (2014), "Renaissance of case research as a scientific method", Journal of Operations Management, Vol. 32, pp. 232-240.

Kim, S. H., Cohen, M., and Netessine, S. 2007. "Performance contracting in after-sales service supply chains”, Management Science, Vol. 53 No. 12, pp. 1843-1858.

Krakovics, F., Leal, J., Mendes, P., and Santos, R.L. (2008), "Defining and calibrating performance indicators of a 4PL in the chemical industry in Brazil", International Journal of Production Economics, Vol. 115, pp. 502-514.

Lai, K.-H., Ngai, E., and Cheng, T.C.E. (2004), “An empirical study of supply chain performance in transport logistics”, International Journal of Production Economics, Vol. 87, pp. 321-331.

Leung, L., Wong, W.H., Van Hui, Y., and Wan, Y. (2013), "Managing third-party logistics under uncertainty: A decision scheme and managerial implications", International Journal of Production Economics, Vol. 145, pp. 630-644.

Liu, W. and Wang, Y. (2015), "Quality control game model in logistics service supply chain based on different combinations of risk attitude", International Journal of Production Economics, Vol. 161, pp. 181-191.

Logan, M. S. (2000), "Using agency theory to design successful outsourcing relationships", International Journal of Logistics Management, Vol. 11 No. 2, pp. 21-32.

Lukassen, P., and Wallenburg, C-M. (2010), "Pricing third party logistics services: Integrating insights from the logistics and industrial services literature”, Transportation Journal, Vol. 49 No. 2, pp. 24-43.

Marasco, A. (2008), “Third-party logistics: A literature review”, International Journal of Production Economics, Vol. 113 No. 1, pp. 127-147.

Martikainen, A., Niemi, P. and Pekkanen, P. (2014), "Developing a service offering for a logistics service provider: Case of local food supply chain”, International Journal of Production Economics, Vol. 157, pp. 318-326.

Marshall, C., and Rossman, G. B. (1999), Designing Qualitative Research, (3rd Ed.), Sage, Thousand Oaks.

Miles, M.B., and Huberman, A.M. (1994), Qualitative Data Analysis: An Expanded Sourcebook, Sage, Newbury Park.

Min, H. and Joo, S.J. (2006), "Benchmarking the operational efficiency of third party logistics providers using data envelopment analysis”, Supply Chain Management: An International Journal, Vol. 11 No. 3, pp. 259-265. 
Ng, I. C. L., Maull, R., and Yip, N. (2009), “Outcome-based contracts as a driver for systems thinking and service-dominant logic in service science: Evidence from the defence industry”, European Management Journal, Vol. 27 No. 6, pp. 377-387.

Oflac, B.S., Sullivan, U.Y., and Baltacioglu, T. (2012), “An attribution approach to consumer evaluations in logistics customer service failure situations", Journal of Supply Chain Management, Vol. 48 No. 4, pp. 51-71.

Patton, M. (1990), Qualitative Evaluation and Research Methods. (2nd Ed.), Sage, Newbury Park, CA.

Prockl, G., Pflaum, A., and Kotzab, H. (2012) “3PL factories or lernstatts? Value creation models for 3PL service providers”, International Journal of Physical Distribution and Logistics Management, Vol. 42 No. 6, pp. 544-561.

Rajesh, R., Pugazhendhi, S., Ganesh, K., Ducq, Y., and Lenny Koh, S. (2012), "Generic balanced scorecard framework for third party logistics service provider”, International Journal of Production Economics, Vol. 140, pp. 269-282.

Randall, W., Pohlen, T., and Hanna, J. (2010), "Evolving a theory of performance-based logistics using insights from service dominant logic", Journal of Business Logistics, Vol. 31 No. 2, pp. 35-61.

Randall, W. S., Nowicki, D., and Hawkins. T. (2011), "Explaining the effectiveness of performance based logistics: A quantitative investigation”, International Journal of Logistics Management, Vol. 22 No. 3, pp. 324-338.

Rossi, S., Colicchia, C., Cozzolino, A. and Christopher, M. (2013), “The logistics service providers in eco-efficiency innovation: an empirical study”, Supply Chain Management: An International Journal, Vol. 18 No. 6, pp. $583-603$.

Rossiter-Hofer, A., Knemeyer, M., and Murphy, P.R. (2015), “Achieving and exceeding logistics outsourcing expectations in Brazil: A replication study”, Transportation Journal, Vol. 54, No. 3, pp. 339-367.

Rossiter-Hofer, A., Knemeyer, M., and Murphy, P.R. (2012), "The roles of procedural and distributive justice in logistics outsourcing relationships", Journal of Business Logistics, Vol. 33 No. 3, pp. 196-209.

Sampson, S. (2000), "Customer-supplier duality and bidirectional supply chains in service organisations”, International Journal of Service Industry Management, Vol. 11 No. 4, pp. 348364.

Sampson, S. E., and Froehle, C. M. (2006), "Foundations and implications of a proposed unified services theory”, Production and Operations Management, Vol. 15 No. 2, pp. 329-343.

Sampson, S. E., and Spring, M. (2012), "Customer roles in the service supply chain and opportunities for innovation”, Journal of Supply Chain Management, Vol. 48 No. 4, pp. 30-50.

Sanchez Rodrigues, V., Harris, I. and Mason, R. (2015), "Horizontal logistics collaboration for enhanced supply chain performance: An international retail perspective”, Supply Chain Management: An International Journal, Vol. 20 No. 6, pp. 631-647.

Schwenk, C.R. (1985), "The use of participant recollection in the modeling of organizational decision processes", Academy of Management Review, Vol. 10 No 3, pp. 496-503.

Selviaridis, K., Matopoulos, A., Szamosi, L. and Psychogios, A. (2016), "Reverse resource exchanges in service supply chains: The case of returnable transport packaging”, Supply Chain Management: An International Journal, Vol. 21 No. 3, pp. 381-397.

Selviaridis, K., and Norrman, A. (2015), "Performance-based contracting for advanced logistics services: Challenges in its adoption, design and management”, International Journal of Physical Distribution \& Logistics Management, Vol. 45 No. 6, pp. 592 - 617.

Selviaridis, K., and Norrman, A. (2014), "Performance-based contracting in service supply chains: A service provider risk perspective”, Supply Chain Management: An International Journal, Vol. 19 No. 2, pp. 153-172.

Selviaridis, K., and Spring, M. (2007), “Third party logistics: A literature review and research agenda”, International Journal of Logistics Management, Vol. 18 No. 1, pp. 125-150.

Shi, Y., Yang, A., Arthanari, T., Liu, Y. and Cheng, T. (2016), “Third party purchase: An empirical study of third-party logistics providers in China", International Journal of Production Economics, Vol. 171, pp. 189-200. 
Strauss, A., and Corbin J. (1990), Basics of Qualitative Research: Grounded Theory Procedures and Techniques, Sage, Newbury Park, CA.

Van Hoek, R.I. (2001), "The contribution of performance measurement to the expansion of third party alliances in the supply chain”, International Journal of Operations and Production Management, Vol. 21 No. 1/2, pp. 15-25.

Van Hoek, R. I., and Chong, I. (2001), "Epilogue: UPS Logistics - Practical approaches to the esupply chain”, International Journal of Physical Distribution and Logistics Management, Vol. 31 No. 6, pp. 463-468.

Vargo, S.L. and Lusch, R.F. (2004), “Evolving to a new dominant logic for marketing”, Journal of Marketing, Vol. 68 No. 1, pp. 1-17.

Voss, C., Tsikriktsis, N., and Frohlich, M. (2002), "Case research in operations management". International Journal of Operations and Production Management, Vol. 22 No. 2, pp. 195-219..

Wagner, S.M., and Sutter, R. (2012), "A qualitative investigation of innovation between third-party logistics providers and customers”, International Journal of Production Economics, Vol. 140 No. 2, pp. 944-958.

Wallenburg, C.M. and Schäffler, T. (2014), “The interplay of relational governance and formal control in horizontal alliances: A social contract perspective”, Journal of Supply Chain Management, Vol. 50 No. 2, pp. 41-58.

Whipple, J. M., and Roh, J. (2010), “Agency theory and quality fade in buyer-supplier relationships”, International Journal of Logistics Management, Vol. 21 No. 3, pp. 338-352.

Wu, Q., Mu, Y., and Feng, Y. (2015), “Coordinating contracts for fresh product outsourcing logistics channels with power structures”, International Journal of Production Economics, Vol. 160, pp. 94-105.

Wynstra, F., Spring, M., and Schoenherr, T. (2015), "Service triads: A research agenda for buyersupplier-customer triads in business services”, Journal of Operations Management, Vol. 35, pp. $1-20$.

Yang, Q. and Zhao, X., Yeung, H.Y.J. and Liu, Y. (2016), "Improving logistics outsourcing performance through transactional and relational mechanisms under transaction uncertainties: Evidence from China”, International Journal of Production Economics, Vol. 175, pp. 12-23.

Yang, Q. and Zhao, X. (2015), "Are logistics outsourcing partners more integrated in a volatile environment?”, International Journal of Production Economics, Vol. 171, pp. 211-220.

Yin, R.K. (2003), Case Study Research: Design and Methods, Sage, Thousand Oaks.

Zhang, Y., Lawrence, B. and Anderson, C. (2015), "An agency perspective on service triads: Linking financial and operational performance”, Journal of Operations Management, Vol. 35, pp. 5666. 


\section{Appendix A: The interview guide}

\section{BACKGROUND INFORMATION}

- Organization information (industry, core business, products/services, annual turnover and market share, key customers/suppliers)

- What is your position/role in relation to the company's organizational structure?

- What does your job entail?

THE SUPPLY CHAIN

- What is the structure/mapping of the customer's supply chain?

- What is the key material and information flows in the customer's supply chain?

- What is the scope of the provided logistics service(s)?

- Can you briefly describe the services provided within the customer's supply chain?

- What is the role and input of key parties (LSP, customer, any sub-contractors) in service performance achievement?

\section{MANAGING RELATIONSHIPS}

- Can you briefly provide an overview of customer/LSP relationship in focus?

- Can you provide a brief account of the customer/LSP relationship history and evolution over time (if applicable)?

- What are the main challenges you face regarding the management of the customer/LSP relationship? (e.g. critical events)

- How LSP-sub-contractor relations are managed and what are the key challenges in managing them?

PERFORMANCE MEASUREMENT AND MANAGEMENT

- How is the service specified in the contract (service specifications)?

- How is 'customer value' defined and measured, if at all?

- How is performance defined in the LSP-customer contract in terms of KPIs and service level targets?

- $\quad$ Are there any extra-contractual performance measures (e.g. operational KPIs)?

- How service performance and KPIs are measured and managed?

- What kinds of performance measurement and management systems are being used?

- How is service performance reported?

\section{PERFORMANCE ATTRIBUTION}

- How service performance (KPI results) can be attributed to specific actions? To what extent?

- What do you perceive as key challenges regarding performance attribution? Any examples?

- What are the key causes of such attribution challenges, if any?

- How does service co-production influence performance measurement and management?

- How difficult/easy is to clearly separate and agree the required service inputs of each party involved in service delivery?

- What are the effects of attribution challenges on the LSP-customer relationship?

- What is the organization's attitude towards performance-related risks? What factors influence this attitude?

- Are you prepared to accept an increased amount of risk in this specific customer/LSP contract? Under what conditions?

- How are these effects managed within the LSP-customer relationship?

- How can the performance measurement system in place take into account attribution issues?

- What is the design of the payment mechanism included in the customer/LSP contract and why?

- How is financial risk allocated and managed in this contract?

- What other clauses of the contract relate to performance and risk allocation/delimitation?

- What is the role of collaboration and trust vis-à-vis the formal contract in managing attribution challenges in the LSP-customer relationship? 


\section{Appendix B: The list of interviewed managers}

\begin{tabular}{ll}
\hline Case study & LSP interviewees \\
\hline Case A & 1. Global Key Account Manager \\
2. Global Key Account Manager \\
3. Manager Air \& Outsourcing, Global Accounts \\
4. Ocean Freight and Air Manager, Operations \\
5. Manager Air \& Outsourcing, Global Accounts \\
\\
Case B \\
1. Managing Director \\
2. Operations Director \\
3. BD Manager, Business Control \& Development \\
4. BD Manager, Business Control \& Development \\
5. Business Developer, Business Control \& Development \\
6. BD Manager, Business Control \& Development \\
7. Business Developer, Business Control \& Development \\
8. Business Developer, Business Control \& Development \\
9. BD Manager, Business Control \& Development \\
10. BD Manager, Business Control \& Development \\
11. Logistics Network Manager, Distribution Network \\
12. BD Manager \& Logistics Network Manager \\
13. BD Manager \& Business Developer \\
14. Logistics Network Manager, Distribution Network \\
15. Operations Director
\end{tabular}

Case C 1. Vice President, Global BD

2. BD General Manager, Inbound transport

3. BD General Manager, Outbound transport

4. BD General Manager, Packaging

5. Key Account Manager 1, BD

6. Key Account Manager 2, BD

7. Key Account Manager 3, BD

8. Internal Control Manager, BD

9. Operations Manager, Distribution Planning \& Control

10. Operations Manager \& Traffic Coordinator,

Operations

11. Legal Counsel, Legal

12. Insurance Purchaser \& Damage Prevention \& Claims

Handling Manager, Risk Management

13. Financial \& Control Manager, Finance

14. Vice President, Purchasing

15. Internal Control Manager, BD

\section{Non-LSP interviewees}

6. Global Supply Manager and Outbound Logistics Manager (Customer firm)

16. General Manager, Service subcontractor employed by LSP

16. Managing Director, Service sub-contractor employed by LSP 
Antecedents

Effects

Managing the effects

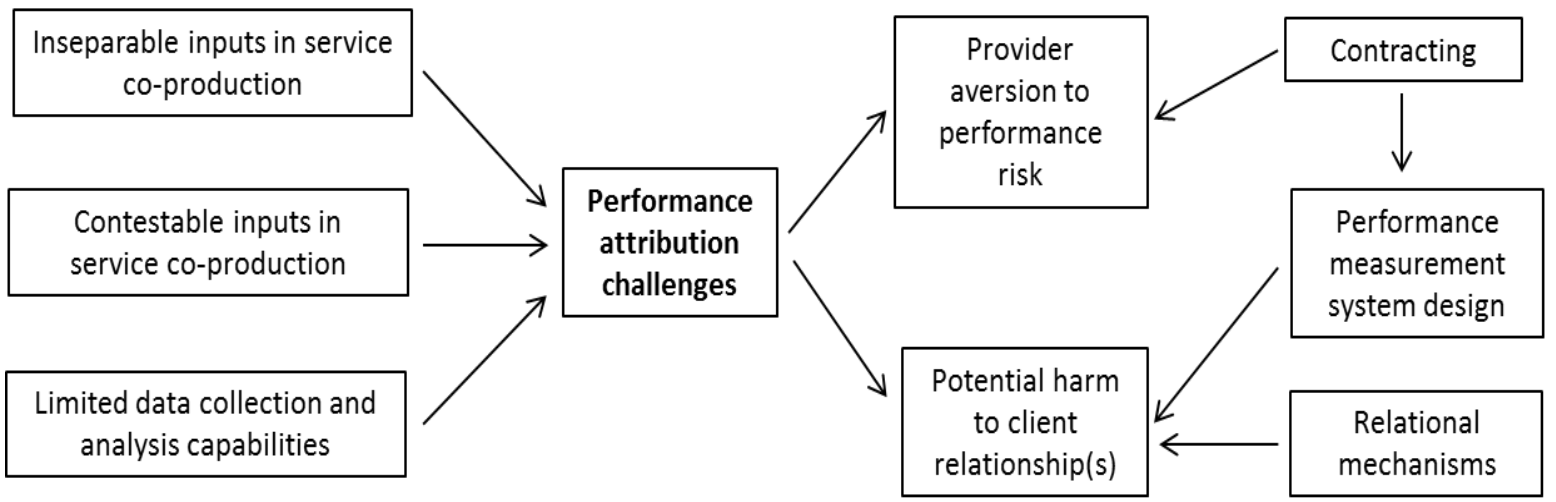

Figure 1. Antecedents and effects of performance attribution challenges in outsourced service provision in supply chains 


\begin{tabular}{|c|c|c|c|}
\hline & Case A & Case B & Case C \\
\hline LSP firm & $\begin{array}{l}\text { Logistics provider } \\
\text { specialising in freight } \\
\text { forwarding and air and } \\
\text { ocean freight transport }\end{array}$ & $\begin{array}{l}\text { Fourth-party logistics } \\
\text { provider specialising in the } \\
\text { food retail market }\end{array}$ & $\begin{array}{l}\text { Logistics provider } \\
\text { specialising mainly in the } \\
\text { automotive industry }\end{array}$ \\
\hline Market expertise & $\begin{array}{l}\text { Industrial, FMCG, fashion, } \\
\text { retail }\end{array}$ & $\begin{array}{l}\text { Food retail, pharma, } \\
\text { healthcare }\end{array}$ & $\begin{array}{l}\text { Automotive, aerospace, } \\
\text { industrial }\end{array}$ \\
\hline No of employees & 30,000 & 80 & 1,200 \\
\hline Turnover & $€ 6,800$ million & $€ 90$ million & $€ 1,069$ million \\
\hline Client firm & $\begin{array}{l}\text { Manufacturer of packaging } \\
\text { solutions and industrial } \\
\text { packaging production } \\
\text { machines }\end{array}$ & $\begin{array}{l}\text { International food retailer } \\
\text { operating also a chain of } \\
\text { in-store restaurants. }\end{array}$ & $\begin{array}{l}\text { Manufacturer of cars and } \\
\text { auto engines }\end{array}$ \\
\hline Industry & Packaging & Food retail & Automotive \\
\hline No of employees & 23,540 & 30,000 & 21,500 \\
\hline Turnover & $€ 11,075$ million & $€ 1,400$ million & $€ 13,200$ million \\
\hline $\begin{array}{l}\text { Services provided by LSP } \\
\text { to client firm }\end{array}$ & $\begin{array}{l}\text { Logistics Control Tower } \\
\text { solution: Freight } \\
\text { forwarding, shipment } \\
\text { booking \& coordination, } \\
\text { customs clearance, invoice } \\
\text { administration and cost } \\
\text { control, carrier tendering \& } \\
\text { performance monitoring. }\end{array}$ & $\begin{array}{l}\text { SCM solution: Supply \& } \\
\text { demand management, } \\
\text { product purchasing, ERP } \\
\text { solution, business } \\
\text { development \& consulting, } \\
\text { finance/administration, } \\
\text { logistics network } \\
\text { management, inventory } \\
\text { ownership \& management. }\end{array}$ & $\begin{array}{l}\text { Logistics and freight } \\
\text { management solution: } \\
\text { Inbound \& outbound } \\
\text { transportation } \\
\text { management, returnable } \\
\text { packaging services, freight } \\
\text { insurance services, quality } \\
\text { control \& maintenance } \\
\text { services, and logistics } \\
\text { consulting. }\end{array}$ \\
\hline
\end{tabular}

Table 1. Background information about the case study companies

\begin{tabular}{|c|c|c|c|}
\hline & Case A & Case B & Case $\mathrm{C}$ \\
\hline \multirow{5}{*}{$\begin{array}{l}\text { Service level } \\
\text { peformance } \\
\text { metrics }\end{array}$} & Deliveries accuracy \% & $\begin{array}{l}\text { Product availability \% (at store } \\
\text { and central warehouse) }\end{array}$ & Packaging availability \%; \\
\hline & $\begin{array}{l}\text { Accuracy of sailing list when } \\
\text { using multiple carriers \% }\end{array}$ & Transport delivery accuracy \% & Packaging delivery precision \%; \\
\hline & CO2 emissions reduction \% & Picking accuracy \%; & Transport delivery precision \%; \\
\hline & $\begin{array}{l}\text { End customer satisfaction survey } \\
\text { score (> specified threshold) }\end{array}$ & Product damages \%; & $\begin{array}{l}\text { No of product damages } \\
\text { (compared to max number target } \\
\text { per annum) }\end{array}$ \\
\hline & & 'Perfect orders' (OTIF) \%; & \\
\hline $\begin{array}{l}\text { Financial } \\
\text { performance } \\
\text { metrics }\end{array}$ & $\begin{array}{l}\text { Total freight cost reduction \% } \\
\text { Ocean freight cost reduction \% } \\
\text { Logistics cost reduction related to } \\
\text { provider innovation \% }\end{array}$ & $\begin{array}{l}\text { Supply chain cost reduction \% } \\
\text { (as compared to cost baseline in } \\
\text { previous year) }\end{array}$ & $\begin{array}{l}\text { Annual logistics cost savings \% in } \\
\text { terms of efficient transport and } \\
\text { returnable packaging solutions (as } \\
\text { compared to cost baseline in } \\
\text { previous year) }\end{array}$ \\
\hline \multirow[t]{2}{*}{$\begin{array}{l}\text { Payment } \\
\text { mechanism }\end{array}$} & $\begin{array}{l}\text { Unit-price for shipment } \\
\text { administration (per shipment) plus } \\
\text { incentive fee (bonus /malus } \\
\text { payment) calcuated based on } \\
\text { overall score (weighted KPIs). }\end{array}$ & $\begin{array}{l}\text { Fixed price plus incentive fee } \\
\text { structure. Incentive fee (bonus) } \\
\text { is linked to "product } \\
\text { availability" and "supply chain } \\
\text { cost reduction" targets as } \\
\text { specified by client }\end{array}$ & $\begin{array}{l}\text { No performance-oriented } \\
\text { incentives agreed. } \\
\text { Cost-plus management fee for } \\
\text { transport management services. }\end{array}$ \\
\hline & $\begin{array}{l}\text { Gain share model for logistics cost } \\
\text { reduction \% as result of } \\
\text { innovation (e.g. }>20 \% \text { savings } \\
\text { leads to } 50-50 \text { split of savings) }\end{array}$ & & $\begin{array}{l}\text { Unit-price pricing for packaging } \\
\text { services (per package unit) }\end{array}$ \\
\hline
\end{tabular}

Table 2. Key performance indicators and contract payment mechanisms 


\begin{tabular}{|c|c|c|c|}
\hline & Key themes & Representative quotes & Interviewees \\
\hline \multirow[t]{2}{*}{$\begin{array}{l}\text { Performance } \\
\text { attribution } \\
\text { challenges }\end{array}$} & $\begin{array}{l}\text { Challening to clealry } \\
\text { attribute to LSP effort the } \\
\text { following KPI results: } 1 \text { ) }\end{array}$ & $\begin{array}{l}\text { It's not easy to isolate who is impacting what, that's a big } \\
\text { challenge!" }\end{array}$ & $\begin{array}{l}\text { Global Supply } \\
\text { Manager (Client } \\
\text { firm) }\end{array}$ \\
\hline & $\begin{array}{l}\text { On time ocean freight } \\
\text { deliveries, 2) Freight cost } \\
\text { reduction, 3) CO2 } \\
\text { emissions reduction, and 4) } \\
\text { Logistics cost reduction } \\
\text { related to provider-led } \\
\text { innovation }\end{array}$ & $\begin{array}{l}\text { "We are always trying to improve but in some areas it was } \\
\text { quite difficult to over-perform since there are a lot of } \\
\text { factors that we cannot control ourselves". }\end{array}$ & LSP Global KAM \\
\hline \multirow[t]{5}{*}{ Antecedents } & $\begin{array}{l}\text { LSP input to CO2 emissions } \\
\text { reduction tough to separate } \\
\text { from others' inputs due to } \\
\text { interdependent decisions }\end{array}$ & $\begin{array}{l}\text { "The air freight shipments are mostly driven by } \\
\text { commercial decisions, and it's definitely in the opposite } \\
\text { direction of what the KPIs try to achieve". }\end{array}$ & $\begin{array}{l}\text { LSP Operations } \\
\text { Manager }\end{array}$ \\
\hline & $\begin{array}{l}\text { Required inputs from client } \\
\text { and sub-contractors; effect } \\
\text { of uncontrollable factors } \\
\text { and how to account for } \\
\text { them }\end{array}$ & $\begin{array}{l}\text { "The customer needs to place the bookings earlier, to plan } \\
\text { this and that, to provide us with the packing lists and all the } \\
\text { correct information [...] they have problems to get the } \\
\text { instructions from their customers, they are pushing them to } \\
\text { get the information in good time so that we can plan the } \\
\text { transports". }\end{array}$ & $\begin{array}{l}\text { LSP Air \& } \\
\text { Outsourcing } \\
\text { Manager }\end{array}$ \\
\hline & & $\begin{array}{l}\text { "The machines must be carried under deck and we have } \\
\text { been discussing if we could find a way to avoid water } \\
\text { damaging the machines and carry them on deck and save } \\
\text { some time and cost [...] they [the customer] are trying to } \\
\text { change the product structure and this can have a big } \\
\text { impact on cost and lead time...but for their production } \\
\text { department is not that easy". }\end{array}$ & $\begin{array}{l}\text { LSP Air \& } \\
\text { Outsourcing } \\
\text { Manager }\end{array}$ \\
\hline & & $\begin{array}{l}\text { "The transport accuracy KPI is hard to hit because we are } \\
\text { dependent on carriers" performance...we could somehow } \\
\text { affect that by changing the mix of modes but still at the end } \\
\text { of the day we are at the hands of the carriers". }\end{array}$ & LSP Global KAM \\
\hline & $\begin{array}{l}\text { LSP limited capability in } \\
\text { performance data analysis } \\
\text { and innovations } \\
\text { documentation }\end{array}$ & $\begin{array}{l}\text { "Are we good enough at analyzing the data? I don't think } \\
\text { so. We have to see if all the data we are collecting are } \\
\text { relevant, if we are utilizing the right parts of the data". }\end{array}$ & LSP Global KAM \\
\hline \multirow[t]{2}{*}{ Effects } & $\begin{array}{l}\text { Aversion to financial risk } \\
\text { re: } \mathrm{CO} 2 \text { emissions and } \\
\text { freight cost reduction and } \\
\text { effort to delimit risk }\end{array}$ & $\begin{array}{l}\text { "We will make sure that air freight shipments driven by } \\
\text { commercial decisions are excluded from the } \\
\text { measurements...we should have done it last year! And we } \\
\text { need to adjust the factor used to calculate CO2 emissions } \\
\text { because it is based on old technologies [...] things have } \\
\text { changed with slow steaming and new engine standards". }\end{array}$ & LSP Global KAM \\
\hline & $\begin{array}{l}\text { Perceived client } \\
\text { opportunism and unfair } \\
\text { allocation of performance } \\
\text { gains }\end{array}$ & $\begin{array}{l}\text { "I think we have the ideas. We know we are improving but } \\
\text { we are not good at telling them what we do. But then we } \\
\text { also have discussions and then they say we don't have time } \\
\text { now...and then suddenly they pick up the idea and use it". }\end{array}$ & $\begin{array}{l}\text { LSP Air \& } \\
\text { Outsourcing } \\
\text { Manager }\end{array}$ \\
\hline $\begin{array}{l}\text { Managing } \\
\text { effects }\end{array}$ & $\begin{array}{l}\text { Contract payment } \\
\text { mechanism design; } \\
\text { Attributability indices in } \\
\text { performance measurement; } \\
\text { Extra-contractual } \\
\text { arrangements/ stipulated } \\
\text { penalty not paid by LSP }\end{array}$ & $\begin{array}{l}\text { "There was a paradox; even though we got the savings we } \\
\text { wanted and even higher, the overall score was still below } \\
\text { the overall target. So we didn't want to get the penalty } \\
\text { since the savings were far higher than expected [...] } \\
\text { performance in this respect [carbon emissions] was } \\
\text { affected by decisions of market companies [end customers] } \\
\text { regarding air freight use". }\end{array}$ & $\begin{array}{l}\text { Oubound } \\
\text { Logistics } \\
\text { Manager (Client } \\
\text { firm) }\end{array}$ \\
\hline
\end{tabular}

Table 3. Performance attribution challenges antecedents and effects in Case A 


\begin{tabular}{|c|c|c|c|}
\hline & Key themes & Representative quotes & Interviewees \\
\hline $\begin{array}{l}\text { Performance } \\
\text { attribution } \\
\text { challenges }\end{array}$ & $\begin{array}{l}\text { Difficulties of attributing } \\
\text { supply chain cost } \\
\text { reduction results to LSP } \\
\text { efforts and actions, as } \\
\text { opposed to other parties } \\
\text { and uncontrollable } \\
\text { environmental inputs }\end{array}$ & $\begin{array}{l}\text { "The noise in this big supply chain is quite substantial, some } \\
\text { [food] suppliers change range, some volumes go that } \\
\text { way...so there is a lot of noise when you are trying to } \\
\text { measure cost improvements...and this variation means that } \\
\text { we won't be able to measure the improvements as clear as } \\
\text { we would like to connect them to our revenue". }\end{array}$ & $\begin{array}{l}\text { LSP BD } \\
\text { Manager }\end{array}$ \\
\hline \multirow[t]{6}{*}{ Antecedents } & $\begin{array}{l}\text { Warehouse and transport } \\
\text { cost efficiency gains in } \\
\text { shared-service settings } \\
\text { difficult to separate }\end{array}$ & $\begin{array}{l}\text { "A } 3 P L \text { provider has a lot of other clients, so how do you } \\
\text { separate out our cost, the sub-contractors say. Because the } \\
\text { idea of } 3 P L \text { warehousing is sharing cost and sharing man- } \\
\text { hours; it's really difficult". }\end{array}$ & $\begin{array}{l}\text { LSP Logistics } \\
\text { Network } \\
\text { Manager }\end{array}$ \\
\hline & $\begin{array}{l}\text { Effect of client product } \\
\text { volumes not easily } \\
\text { separable from LSP input } \\
\text { to supply chain cost } \\
\text { efficiency }\end{array}$ & $\begin{array}{l}\text { "We have suggested that we want a model based on volume } \\
\text { but without given the benefits for things that could be done } \\
\text { without our support. Because volumes can go up with } \\
\text { building new stores which has nothing to do with our cost } \\
\text { efficiency performance". }\end{array}$ & $\begin{array}{l}\text { LSP Managing } \\
\text { Director }\end{array}$ \\
\hline & $\begin{array}{l}\text { Required input from } \\
\text { client and its customers } \\
\text { (stores) to accept reduced } \\
\text { service levels }\end{array}$ & $\begin{array}{l}\text { "We will need their [customer] support, absolutely, because } \\
\text { we can't impact much without their changes [...] if we don't } \\
\text { change the ways the stores order or reduce frequencies of } \\
\text { deliveries [...] there cannot be the savings they are looking } \\
\text { for without a change of methodology, a change of thinking". }\end{array}$ & $\begin{array}{l}\text { LSP Operations } \\
\text { Director }\end{array}$ \\
\hline & $\begin{array}{l}\text { Discussion about how to } \\
\text { manage uncontrollable } \\
\text { environmental inputs }\end{array}$ & $\begin{array}{l}\text { "The value-add index connects to the core service, because } \\
\text { we cannot forecast the complexity of operations based on } \\
\text { number of deliveries, number of markets, and so on". }\end{array}$ & $\begin{array}{l}\text { LSP BD } \\
\text { Manager }\end{array}$ \\
\hline & $\begin{array}{l}\text { Sub-contractor input into } \\
\text { cost efficiency contested }\end{array}$ & $\begin{array}{l}\text { "They [LSP] are the supply chain managers...they are } \\
\text { telling us what to do [...] we don't have the big picture, they } \\
\text { own it, and they have to take responsibility for all this". }\end{array}$ & $\begin{array}{l}\text { General } \\
\text { Manager } \\
\text { (Sub-contractor) }\end{array}$ \\
\hline & $\begin{array}{l}\text { Limited capability to } \\
\text { measure and attribute } \\
\text { client-specific savings }\end{array}$ & $\begin{array}{l}\text { "...you don't have the unit cost for picking a carton for that } \\
\text { customer; usually use the average of picking for everyone. } \\
\text { So it would be hard for them [sub-contractors] to provide } \\
\text { actual cost of doing business on behalf of us” }\end{array}$ & $\begin{array}{l}\text { LSP Logistics } \\
\text { Network } \\
\text { Manager }\end{array}$ \\
\hline \multirow[t]{2}{*}{ Effects } & $\begin{array}{l}\text { LSP aversion to excessive } \\
\text { risk re: supply chain cost } \\
\text { reduction }\end{array}$ & $\begin{array}{l}\text { "I think we will end up with a bonus system that is weak in } \\
\text { terms of driving incentives [...] it is very hard to reach these } \\
\text { [cost saving] targets [...] if they are not achievable, the } \\
\text { bonus will be something that we will not budget for". }\end{array}$ & $\begin{array}{l}\text { LSP Business } \\
\text { Developer }\end{array}$ \\
\hline & $\begin{array}{l}\text { LSP fears of potential } \\
\text { damage to client } \\
\text { relationship (finger- } \\
\text { pointing culture) }\end{array}$ & $\begin{array}{l}\text { "...there won't be any follow up in terms of who is } \\
\text { responsible for savings, who should be doing what to } \\
\text { achieve those and this kind of "ping-pong” dialogue of who } \\
\text { is to blame [...] this can damage the relationship" }\end{array}$ & $\begin{array}{l}\text { LSP BD } \\
\text { Manager }\end{array}$ \\
\hline \multirow[t]{2}{*}{$\begin{array}{l}\text { Managing } \\
\text { effects }\end{array}$} & $\begin{array}{l}\text { LSP emphasis on fixed } \\
\text { fee element; Ongoing } \\
\text { performance review } \\
\text { mentality; }\end{array}$ & $\begin{array}{l}\text { "I think from our point of view is important that we have a } \\
\text { large fixed element to lean back on and say that we have } \\
\text { secured the health of the business. It's not a profitable } \\
\text { business unless we are successful with the bonus, but at least } \\
\text { it is a healthy business if we only get the fixed fee". }\end{array}$ & $\begin{array}{l}\text { LSP BD } \\
\text { Manager }\end{array}$ \\
\hline & $\begin{array}{l}\text { Collaboration, trust and } \\
\text { win-win mentality in } \\
\text { focus }\end{array}$ & $\begin{array}{l}\text { "I mean it [the bonus for cost reduction] should be based on } \\
\text { transparency and trust...this is what we want to have as a } \\
\text { margin, at least as basis, and then let's test this model and } \\
\text { we can revert, because then you can build trust". }\end{array}$ & $\begin{array}{l}\text { LSP Managing } \\
\text { Director }\end{array}$ \\
\hline
\end{tabular}

Table 4. Performance attribution challenges antecedents and effects in Case B 


\begin{tabular}{|c|c|c|c|}
\hline & Key themes & Representative quotes & Interviewees \\
\hline $\begin{array}{l}\text { Performance } \\
\text { attribution } \\
\text { challenges }\end{array}$ & $\begin{array}{l}\text { Challenging to attribute to } \\
\text { LSP effort, as opposed to } \\
\text { effort of other parties, the } \\
\text { following performance } \\
\text { results: 1) logistics cost } \\
\text { savings, and 2) packaging } \\
\text { availability, and 3) } \\
\text { packaging delivery precision }\end{array}$ & $\begin{array}{l}\text { "...we sometimes have discussions with customers what is } \\
\text { theirs and our contribution. Logistics of course is relative } \\
\text { to the actions[...] So we do have some interesting } \\
\text { discussions with customers and some of them they are } \\
\text { trying to hold us responsible for the logistics performance } \\
\text { overall, regardless if it's due to structural changes, change } \\
\text { of supplier base, change of destination, fuel, currency and } \\
\text { so on. }\end{array}$ & $\begin{array}{l}\text { LSP Vice } \\
\text { President BD }\end{array}$ \\
\hline \multirow[t]{5}{*}{ Antecedents } & $\begin{array}{l}\text { Difficult to separate LSP } \\
\text { inputs into cost efficiency } \\
\text { synergies achieved. }\end{array}$ & $\begin{array}{l}\text { "They [the customer] want more of an open-book } \\
\text { relationship with high transparency. But if you have a } \\
\text { group of people working with all customers, then it is } \\
\text { difficult to break down this cost and state specifically how } \\
\text { much it costs to work with them as opposed to other } \\
\text { customers...plus this can change over time also". }\end{array}$ & $\begin{array}{l}\text { LSP Internal } \\
\text { Control } \\
\text { Manager }\end{array}$ \\
\hline & $\begin{array}{l}\text { Required client input e.g. in } \\
\text { terms of timely information } \\
\text { sharing and volume } \\
\text { commitments }\end{array}$ & $\begin{array}{l}\text { "We buy yearly volume [from carriers], we have 10,000 } \\
\text { cars...can you take them over the year? But if you get } \\
10,000 \text { cars in December, they won't cope with it [...] all of } \\
\text { a sudden they [carriers] say we have a problem". }\end{array}$ & $\begin{array}{l}\text { LSP } \\
\text { Operations } \\
\text { Manager }\end{array}$ \\
\hline & & $\begin{array}{l}\text { "They [customer] don't commit to these volumes [...] and } \\
\text { that also affects the carrier side". }\end{array}$ & $\begin{array}{l}\text { LSP } \\
\text { Operations } \\
\text { Manager }\end{array}$ \\
\hline & $\begin{array}{l}\text { Required input from the } \\
\text { client's suppliers in terms of } \\
\text { appropriate use of packages }\end{array}$ & $\begin{array}{l}\text { "When the package is used by these suppliers to serve the } \\
\text { customer, then this becomes also part of the inbound flow } \\
\text { to customer plants [...] if they [customer's suppliers] have } \\
\text { too much packaging, then we ask them to pay a rent for } \\
\text { packaging or if they have too little, then we charge them for } \\
\text { missing packaging". }\end{array}$ & $\begin{array}{l}\text { LSP Internal } \\
\text { Control } \\
\text { Manager }\end{array}$ \\
\hline & $\begin{array}{l}\text { Limited LSP capability in } \\
\text { data collection and analysis }\end{array}$ & $\begin{array}{l}\text { "[. . .] we do it manually today so we have to have a } \\
\text { system, to get everything into the system [. . .] and we need } \\
\text { to make sure that the input data are correct, so that you } \\
\text { have the fundamentals". }\end{array}$ & $\begin{array}{l}\text { LSP BD } \\
\text { Manager, } \\
\text { Packaging }\end{array}$ \\
\hline \multirow[t]{3}{*}{ Effects } & $\begin{array}{l}\text { LSP aversion to financial } \\
\text { risk related to 'pay for } \\
\text { performance' incentives }\end{array}$ & $\begin{array}{l}\text { "Currently we are risk averse. We are trying to change that } \\
\text { but over the last ten years we have become more and more } \\
\text { risk averse for some reason". }\end{array}$ & $\begin{array}{l}\text { LSP Vice } \\
\text { President BD }\end{array}$ \\
\hline & $\begin{array}{l}\text { Client perception of lack of } \\
\text { costing and pricing } \\
\text { transparency }\end{array}$ & $\begin{array}{l}\text { "[The main challenge is] to offer them [customer] } \\
\text { transparency. Because they want an open-book philosophy } \\
\text { and we haven't been good at offering that. So there are } \\
\text { issues around trust and whether the prices we quote them } \\
\text { are the correct ones, [customer] people wonder". }\end{array}$ & $\begin{array}{l}\text { LSP Internal } \\
\text { Control } \\
\text { Manager }\end{array}$ \\
\hline & & $\begin{array}{l}\text { "[...] we need to revitalize the business relationship } \\
\text { because we understand that it is not healthy right now". }\end{array}$ & $\begin{array}{l}\text { LSP Global } \\
\text { KAM }\end{array}$ \\
\hline $\begin{array}{l}\text { Managing } \\
\text { effects }\end{array}$ & $\begin{array}{l}\text { Delimiting LSP risk and } \\
\text { liabilities related to } \\
\text { performance through } \\
\text { contracting }\end{array}$ & $\begin{array}{l}\text { "We don't accept penalties [...] well...you can turn it the } \\
\text { other way around and perhaps say if we perform our } \\
\text { services and reach our goals, then we can receive extra } \\
\text { money. But I am not so happy about that either. You should } \\
\text { always do your best. So then why should you receive extra } \\
\text { money if you are doing your best?" }\end{array}$ & $\begin{array}{l}\text { LSP Legal } \\
\text { Counsel }\end{array}$ \\
\hline
\end{tabular}

Table 5. Performance attribution challenges antecedents and effects in Case $C$ 


\begin{tabular}{|c|c|c|c|}
\hline & Case A & Case B & Case C \\
\hline \multicolumn{4}{|l|}{ Antecedents } \\
\hline $\begin{array}{l}\text { Inseperable inputs } \\
\text { in service } \\
\text { co-production }\end{array}$ & $\begin{array}{l}\text { LSP input into CO2 emissions } \\
\text { reduction performance difficult to } \\
\text { separate from decisions and actions } \\
\text { of the client and its customers (e.g. } \\
\text { order pattern, production lead } \\
\text { times) as well as sub-contractor } \\
\text { capacity planning decisions }\end{array}$ & $\begin{array}{l}\text { Scale economies and cost } \\
\text { synergies arising from LSP } \\
\text { and sub-contractors serving } \\
\text { multiple clients; difficult to } \\
\text { separate cost efficiency } \\
\text { gains/losses from changes in } \\
\text { client's and its customers' } \\
\text { (stores) product volumes }\end{array}$ & $\begin{array}{l}\text { Cost synergies arising from } \\
\text { LSP and sub-contractors } \\
\text { serving multiple clients; } \\
\text { difficult to separate LSP inputs } \\
\text { in cost efficiency from those of } \\
\text { sub-contractors and other } \\
\text { parties }\end{array}$ \\
\hline $\begin{array}{l}\text { Contestable inputs } \\
\text { in service } \\
\text { co-production }\end{array}$ & $\begin{array}{l}\text { Required client inputs in cost } \\
\text { reduction and innovation outcomes } \\
\text { e.g. product design changes; } \\
\text { required shipping lines' input in } \\
\text { timely deliveries;discussions about } \\
\text { the effect of uncontrollable inputs } \\
\text { (e.g. freight market rates) on cost } \\
\text { reduction and how to account for } \\
\text { them. }\end{array}$ & $\begin{array}{l}\text { Cost reduction requires } \\
\text { convincing stores to accept } \\
\text { reduced service levels; } \\
\text { dicussion about who should } \\
\text { manage uncontrollable factors } \\
\text { at play e.g. regulatory } \\
\text { changes; sub-contractor input } \\
\text { to cost efficiency contested }\end{array}$ & $\begin{array}{l}\text { Client required to provide } \\
\text { timely information of volume } \\
\text { forecasts; client and its } \\
\text { suppliers' role in packaging } \\
\text { availability; client's (lack of) } \\
\text { commitment to product } \\
\text { volumes impacts on LSP and } \\
\text { sub-contractor efficiency }\end{array}$ \\
\hline $\begin{array}{l}\text { Limited data } \\
\text { collection/analysis } \\
\text { capabilities }\end{array}$ & $\begin{array}{l}\text { LSP lack of capabilities in } \\
\text { performance data analysis; no } \\
\text { systematic documention of } \\
\text { innovative ideas and their } \\
\text { implementation }\end{array}$ & $\begin{array}{l}\text { Measurement system not } \\
\text { capable to attribute LSP and } \\
\text { sub-contractor cost savings to } \\
\text { customer-specific operations }\end{array}$ & $\begin{array}{l}\text { Lack of capable systems to } \\
\text { collect and analyse performance } \\
\text { and cost data }\end{array}$ \\
\hline \multicolumn{4}{|l|}{ Effects } \\
\hline $\begin{array}{l}\text { Provider aversion } \\
\text { to performance } \\
\text { risk }\end{array}$ & $\begin{array}{l}\text { LSP aversion to performance risk } \\
\text { and efforts to delimit it (e.g. CO2 } \\
\text { emissions KPI) }\end{array}$ & $\begin{array}{l}\text { LSP aversion to risk related to } \\
\text { the supply chain cost } \\
\text { reduction KPI; request for } \\
\text { appropriate intensity of cost } \\
\text { reduction-based bonus }\end{array}$ & $\begin{array}{l}\text { LSP refusal to link service fee } \\
\text { to logistics cost savings and } \\
\text { packaging availability KPIs }\end{array}$ \\
\hline $\begin{array}{l}\text { Potential harm to } \\
\text { client } \\
\text { relationship(s) }\end{array}$ & $\begin{array}{l}\text { LSP perceptions of client } \\
\text { opportunism in relation to } \\
\text { innovation ideas implementation } \\
\text { and perceived unfairness of } \\
\text { performance incentives }\end{array}$ & $\begin{array}{l}\text { Potential detrimental effects } \\
\text { of performance attribution to } \\
\text { client relationship due to } \\
\text { encouragement of a 'finger- } \\
\text { pointing' culture }\end{array}$ & $\begin{array}{l}\text { Client's perceived lack of } \\
\text { transparency of service costs } \\
\text { and pricing }\end{array}$ \\
\hline \multicolumn{4}{|l|}{ Managing effects } \\
\hline Contracting & $\begin{array}{l}\text { Penalty/bonus only small \% of total } \\
\text { service fee; contract re-design in } \\
\text { terms of KPI definition and } \\
\text { weighting }\end{array}$ & $\begin{array}{l}\text { Provider emphasis on } \\
\text { securing a reasonable fixed } \\
\text { fee; Cost reduction bonus of } \\
\text { secondary importance }\end{array}$ & $\begin{array}{l}\text { Provider payment not tied to } \\
\text { KPIs; adherence to unit-price } \\
\text { and cost-plus mechanisms. } \\
\text { Delimited provider liability for } \\
\text { non-performance excluding also } \\
\text { 'consequential losses' }\end{array}$ \\
\hline $\begin{array}{l}\text { Performance } \\
\text { measurement } \\
\text { system deign }\end{array}$ & $\begin{array}{l}\text { 'Controllability’ and } \\
\text { 'accountability’ indeces connected } \\
\text { to KPI measurement; three-way } \\
\text { performance review meetings }\end{array}$ & $\begin{array}{l}\text { Ongoing performance } \\
\text { analysis and identification of } \\
\text { corrective actions without } \\
\text { attribution indices }\end{array}$ & \\
\hline $\begin{array}{l}\text { Relational } \\
\text { mechanisms }\end{array}$ & $\begin{array}{l}\text { Stipulated financial penalty was not } \\
\text { paid by provider to maintain } \\
\text { collaboration and re-institute } \\
\text { fairness in allocation of gains }\end{array}$ & $\begin{array}{l}\text { Emphasis on 'team effort', } \\
\text { collaboration, trust, flexibility } \\
\text { and win-win mentality }\end{array}$ & \\
\hline
\end{tabular}

Table 6. Antecedents and effects of performance attribution challenges across the cases 